\title{
Formas colectivas de habitar en zonas mineras del sur de Chile. Los casos de Puchoco- Schwager (Bío-Bío) y Puerto Cristal (Aysén)*
}

Collective dwelling forms in mining zones of southern Chile. The cases of Puchoco-Schwager (Bío Bío) and Puerto Cristal (Aysén)

Alejandra Brito P.

Universidad de Concepción, Concepción, Chile. 区 abrito@udec.cl [orcid.org/0000-0001-5279-5982]

\section{RESUMEN}

Este artículo analiza las formas colectivas de habitar en dos zonas mineras del sur del país (la carbonífera Schwager, en Bío-Bío y Puerto Cristal en Aysén). La investigación busca comparar estos espacios alejados de los centros urbanos, y donde las prácticas de paternalismo industrial hacían que la empresa fuera la única que proporcionaba servicios que posibilitaron el bienestar social y familiar. Coinciden en la existencia de una memoria social que configura territorios sociales, con una fuerte identidad, pero diferenciados en sus emplazamientos geográficos. La zona carbonífera logra desarrollar un poblado obrero que a lo largo del siglo XX se inserta en la conurbación del Gran Concepción; en cambio, Puerto Cristal desaparece como poblado-habitado una vez que se cierra la explotación minera. Son los puntos de encuentro y desencuentro de las historias de sus habitantes, lo que queremos dar cuenta en este trabajo.

PALABRAS CLAVE: paternalismo industrial, zonas mineras, memoria social, Puerto Cristal-Aysén, Puchoco-Schwager-Bío-Bío.

\section{ABSTRACT}

This article analyzes the collective ways of dwelling in two mining zones in southern Chile (the coal industry Schwager in Bío-Bío and Puerto Cristal in Aysén). The research attempts to compare these two spaces located far from the urban center, in where practices

* Este trabajo presenta los resultados de los Proyectos CONICYT-PIA Soc 1403 y FONDECYT 1171100 
of industrial paternalism made the company the only source of services that enabled social and familiar welfare. They have a common existence of a social memory that configures social territories based on strong identities, despite being geographically distant. The coal zone was able to develop a worker's settlement which later became part of the urban zone of the Gran Concepción during the twentieth century. Instead, Puerto Cristal disappeared as a populated town after the closure of the factory. The convergences and divergences of their inhabitants' histories are the focus of this research.

KEY WORDS: Industrial Paternalism, Mining Zones, Social Memory, Puerto CristalAysén, Puchoco-Schwager-Bío-Bío.

\section{INTRODUCCIÓN}

El estudio de la minería en Chile ha estado centrado más en el norte y centro del país (Ortega \& Pinto, 1990; Mazzei, 2001; Pinto, 2007; Ortega, 2008), conociéndose poco las experiencias más al sur de la zona carbonífera. Nuestro interés es rescatar la experiencia en el centro-sur y el suraustral. Tomaremos dos casos: Puchoco-Schwager, en la cuenca carbonífera del golfo de Arauco; y Puerto Cristal, una mina de zinc y plomo en el lago General Carrera, Aysén.

Nuestra intención es comparar, bajo la perspectiva del contraste, las dos experiencias, reconociendo diferencias y similitudes (Van der Linden, 1999). Según Charles Tilly (1984), existen cuatro tipos de comparaciones históricas. Primero, la universalizadora, que busca explicar que cada caso particular estudiado sigue la misma regla o patrón. Segundo, la identificación de la diferencia, que intenta dar cuenta de la graduación o los niveles de un fenómeno general. Tercero, la globalizadora, que clasifica los casos investigados como partes diferentes de un sistema u orden de cosas más general. Cuarto, la individualizadora, en la que diferentes realidades son contrastadas con el fin de mostrar las particularidades de cada caso. Este estudio utiliza una mirada mixta en la que la comparación universalizadora se entrecruza con la identificación de la diferencia: por un lado, se pretende mostrar la pertenencia de los casos estudiados a un mismo fenómeno general, el paternalismo industrial; por otro, se intenta reflejar que existieron igualmente condiciones históricas y geográficas que hicieron que cada caso presente sus particularidades.

En sus orígenes ambas instalaciones se emplazaron en zonas con nulo desarrollo urbano. Fueron las propias empresas las que impulsaron un hábitat minero e industrial. Aquí las diferentes temporalidades son claves. La explotación carbonífera comienza a mediados del siglo XIX, período sin regulación del trabajo y con casi nula presencia del Estado, con condiciones de vida muy precarias en sus orígenes, las que logran mejorar debido a la organización y lucha obrera iniciada a fines del mencionado siglo (Grez, 1995). En cambio, Puerto Cristal inicia sus faenas a mediados de la década de 1930, después de la promulgación del Código Laboral en 1931 y el impulso a la actividad vino de la mano del Estado, a través de 
la CORFO. Sin embargo, se debió sortear la dificultad de desplazamientos por el aislamiento geográfico y las escasas fiscalizaciones estatales.

Estas experiencias reflejan formas colectivas de habitar surgidas de prácticas paternalistas de las empresas, constituyéndose como territorios sociales, entendidos como espacios de "construcción de una microsociedad y un territorio por parte de los habitantes locales” (Lindón, 2002, p. 31). Como es propio en las fases tempranas del proceso de industrialización, las prácticas paternalistas permitieron, por un parte fijar a la población y, por otra, desarrollar una mano de obra en la disciplina del trabajo industrial (Terradas i Saborit, 1994). Para que esto tuviese eficacia se instalaron familias, facilitando el control social y la reproducción de la mano de obra, dotando a los asentamientos de una serie de equipamientos y servicios para los trabajadores y sus familias. Como resultado, surge una memoria emblemática: los antiguos trabajadores/as y sus hijos e hijas, herederos de una forma de habitar industrial, reconocen su territorio como patrimonio a resguardar. Ahora bien, a pesar de las similitudes en las experiencias, sí hay un elemento que los distancia: las proyecciones de habitabilidad futura. Hoy Puerto Cristal está deshabitado y PuchocoSchwager incluido en la conurbación del Gran Concepción.

El foco del análisis de este trabajo estará puesto en las formas de habitar, a fin de comprender cómo se ha configurado historiográficamente el espacio, desde la dimensión físico-geográfica en que un poblado se emplaza; y desde lo simbólico, a partir del cual se producen las interacciones de los distintos actores sociales. "El espacio es una construcción social... [donde] las relaciones están también construidas en él y, por tanto, lo social no puede ser teorizado de manera autónoma de las formas e implicaciones espaciales” (Sznol, 2007, p. 28). Siguiendo a Lefebvre (2013), nos interesa relevar el espacio social como una producción de prácticas, saberes, percepciones, que reconoce tres momentos: las prácticas espaciales, las representaciones del espacio y los espacios de representación. Soja (1997) lo especifica como espacialidad, historicidad y socialidad, conformando una trialéctica: un espacio percibido (lo físico o material); el espacio concebido (las representaciones sociales y las construcciones imaginarias) y el espacio vivido (constituido por la experiencia cotidiana).

De esta manera, para entender los espacios de transformación urbana, los movimientos y la identidad colectiva, se debe comprender el lugar concreto donde se constituyen y articulan las identidades, en el cual se desarrolla la acción social del movimiento (Oslender, 2002). Esto lleva necesariamente a relevar la importancia del espacio donde los distintos actores sociales están inmersos y construyen su identidad, incluyendo la acción moldeadora de la ubicación física, las estrategias de trabajo y las opiniones y las estrategias de negociación,

así ...su vivienda les señala su nivel social; el entorno arquitectónico público les indica la naturaleza del poder político, y sus espacios discursivos, en forma de sus propios imaginarios y de las percepciones populares y oficiales, delimitan las posibilidades de su acción social y política (Leidenberger, 2004, p. 74). 
Siguiendo a Leidenberger (2004), debemos entender la existencia de estos poblados mineros a partir de la interrelación entre proximidad y diferenciación. Por una parte, los marcos de proximidad a partir de la concentración de las actividades humanas y lo material; y por otra, los marcos de la diferenciación a partir de funciones distintas, de la segregación física de los habitantes y de la alta diversidad tanto de experiencias, como de imaginarios y expectativas.

En el espacio construido en los poblados mineros estudiados, las empresas aplicaron prácticas paternalistas, las que se insertaron dentro de lo que se ha denominado paternalismo industrial $^{1}$. En la Europa del siglo XIX, este sistema se inscribió dentro de la doctrina social de la iglesia católica y la filantropía, que tomó también elementos del socialismo utópico y del Familisterio de Jean Baptiste Godin (Terradas i Saborit, 1994). Se sustentó en el convencimiento que las burguesías empresariales tenían el deber moral de ayudar y proteger a los obreros, para lo cual los dueños de las industrias construyen equipamientos, destinados al bienestar de los trabajadores y sus familias (Dos Santos, 2014). El objetivo central del paternalismo se define en tres conceptos: atraer - fijar - disciplinar. A partir de este trinomio se configura una red de relaciones que busca transformar a sujetos provenientes de fuera de la disciplina industrial, en obreros productivos, para lo cual fue necesario transformar prácticas laborales ancestrales que, en el caso del trabajador chileno, se definieron en el peonaje (Salazar, 1985; Illanes, 2003), caracterizado por la ausencia de lazos sólidos, tanto familiares como sociolaborales. Así, el paternalismo industrial se instaló como una respuesta a través de diversas políticas de bienestar social. Como plantea Sierra (1990)

...únicamente aspirando a transformar las condiciones de vida del trabajador estarían los patronos en posición de limitarlas a condiciones de reproducción; únicamente aspirando a cubrir las necesidades reales del trabajador en tanto que hombre estarían los patronos en condiciones de responder a sus «necesidades» en tanto que obrero. Únicamente aspirando a la elevación humana del trabajador estarían los patronos en condiciones de reducirlo a obrero modelo (p. 86).

En Chile, la familia obrera se constituyó en un eje clave, surgiendo como una respuesta frente a la crisis de la cuestión social, una vez que la frágil armonía social - como lo vieron las elites - se desmoronaba con las movilizaciones obreras que se desarrollaron a partir de la huelga general de 1890. Así, la instalación de familias en los centros mineros fue una estrategia eficaz, configurando espacios cerrados. Simbólicamente la familia minera se reconoce como la sustentadora de la vida, 'mi segunda madre', 'la que me alimentó', reconociéndose en la

En Chile hay numerosos estudios que incorporan el análisis sobre el paternalismo industrial. En la zona de BíoBío encontramos: Vergara, 2013; Godoy, 2015; Venegas, 2015; Venegas y Morales, 2015, 2017; Brito y Ganter, 2015; Ganter y Brito, 2017. Para el norte salitrero están los trabajos de González, 2002, 2013, 2016; San Francisco et al. 2009; Matus, 2013; González (2017). Para la industria cuprífera Baros, 1996 y 2006; Vergara, 2004 y 2012; Garrido, 2014. Para otros casos destacamos: Sierra, 1990; Terradas i Saborit, 1994 (AGREGAR); Garrigós, 2006; Muñiz, 2007, 2011; Lemiez, 2013. 
familia schwagerina y la familia cristalina. "De esta manera la relación salarial en particular debía disolverse en favor de una relación de naturaleza esencialmente afectiva; la empresa, en suma, debía convertirse en familia" (Sierra, 1990, p. 81).

Lo que nos interesa es comprender el desarrollo de estas dos comunidades, desde su cotidianeidad, recuperando sus propias voces. Para ello dividiremos este trabajo en cuatro partes. La primera es una reseña histórica de la instalación de estos poblados mineros en los territorios; la segunda enfatiza la recuperación de las formas de habitar, a partir de las voces de extrabajadores y sus familias; en la tercera se analiza el impacto del cierre de la producción minera; y, por último, en las reflexiones finales, se discuten las posibilidades de futuro de ambos territorios.

\section{LA INSTALACIÓN MINERA EN LOS TERRITORIOS}

En Chile, la producción minera fue uno de los pilares centrales en la economía postindependencia, insertando el país en los circuitos económicos internacionales (Ortega \& Pinto, 1990). Sus orígenes están en el Norte Chico, donde se explotaban los yacimientos más importantes de cobre y plata. En sus inicios la labor extractiva estaba en manos de productores independientes, de origen popular y en la inversión de capitales de las elites locales, a través del sistema de habilitación, que luego se insertaban en circuitos comerciales internos y externos. La explotación en manos de las elites nacionales e internacionales había generado un proceso de proletarización de los sectores populares mineros a través del crédito y el endeudamiento, jerarquizando la actividad productiva (Illanes, 2003). En el último tercio del siglo XIX este primer ciclo económico de crecimiento minero entró en crisis (asociada a la crisis internacional de 1870), y la búsqueda de salidas a aquélla derivó en la extensión territorial (Mazzei, 2001; Robles, 2009; González, 2014). Hacia el norte se incorporaron las regiones salitreras (una vez anexados los territorios de Perú y Bolivia con el triunfo de Chile en la Guerra del Pacífico). Hacia el sur, se incorporaron las tierras mapuches, aumentando las posibilidades de explotación de la cuenca carbonífera en la frontera al sur del Bío-Bío (Pinto, 2003). La extensión territorial demostró a las elites políticas y económicas su eficacia, manteniéndose como estrategia, tanto económica como geopolítica, en el siglo XX. La ocupación de la zona austral del país a comienzos del siglo XX abre las posibilidades de explorar estos territorios, instalándose varias empresas mineras en la región de Aysén y Magallanes. Con la incorporación del Estado en la actividad económica, a mediados del siglo XX, se dio un nuevo impulso a la actividad minera, a través de la Corporación de Fomento de la Producción-CORFO (Muñoz \& Arriagada, 1977; Ibáñez, 1994; Meller, 1998; Ffrench-Davis, Muñoz, Benavente, \& Crespi, 2020; Ortega, 2018).

La explotación del carbón en la zona de Puchoco² se inicia a mediados del siglo XIX, estimulada por el auge de la producción minera del Norte Chico y la creciente demanda de carbón para las fundiciones. En 1857 comienzan las exploraciones en Punta Puchoco (Fig. 1)

Actualmente pertenece a la comuna de Coronel, en la provincia de Concepción, región del Bío-Bío. 
por la empresa Délano y Cía., en sociedad con Federico Schwager. Con la extensión de la línea férrea hacia el sur del Bío-Bío en 1872 se acelera el poblamiento. En 1892 Federico Schwager compra todos los derechos y funda la Compañía Carbonífera y de Fundición Schwager (Mazzei, 1997), consolidándose el poblado minero, con mayor inversión en desarrollo urbano y productivo (Pérez, 2008). El período que va entre 1920 y 1950 fue la época de mayor auge, transformándose en una ciudad industrial con equipamientos urbanos y mayor habitabilidad. Siguiendo el modelo de poblados segregados, se construyeron viviendas para obreros, en el sector bajo y para técnicos y empleados, en lo alto del cerro. Además, se instalaron servicios comunitarios como hornos y servicios higiénicos. Hacia 1920 se construye un Economato y el retén de Carabineros, luego la plaza y el mercado, la Escuela Industrial Federico Schwager, las escuelas primarias fiscales No 13, 14 y 16, para hijos e hijas de obreros, y la Escuela Particular No6 para los hijos e hijas de empleados; además construyeron una iglesia, un gimnasio y un casino (Ganter \& Brito, 2017). El Servicio Social industrial, a través del Departamento de Bienestar, se convirtió en uno de los pilares del desarrollo de las políticas de bienestar social para trabajadores, que fueron modelando las formas de habitar del territorio bajo el modelo paternalista (Venegas, 2015; Venegas \& Morales, 2015).

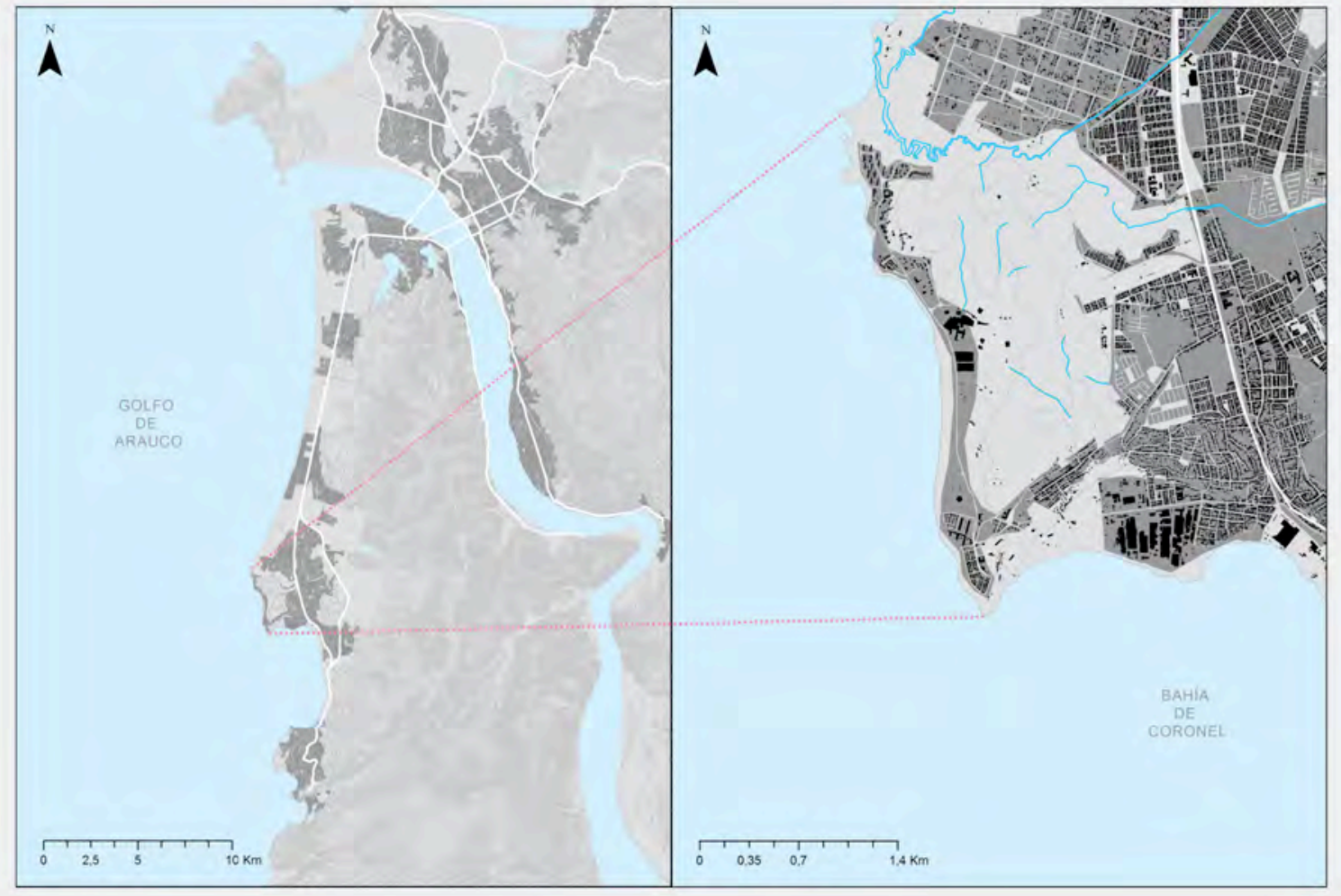

Fig. 1. Mapa de localización de Puchoco-Schwager, Coronel, región del Bío-Bío. Fuente: Elaboración propia. 


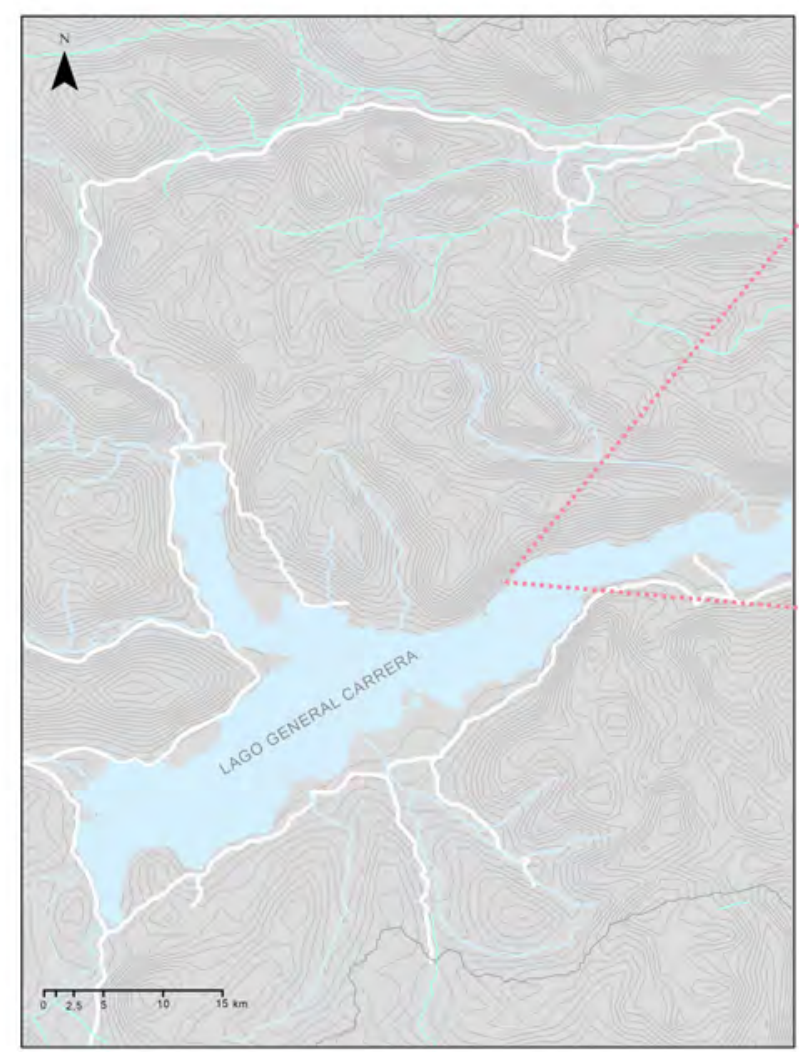

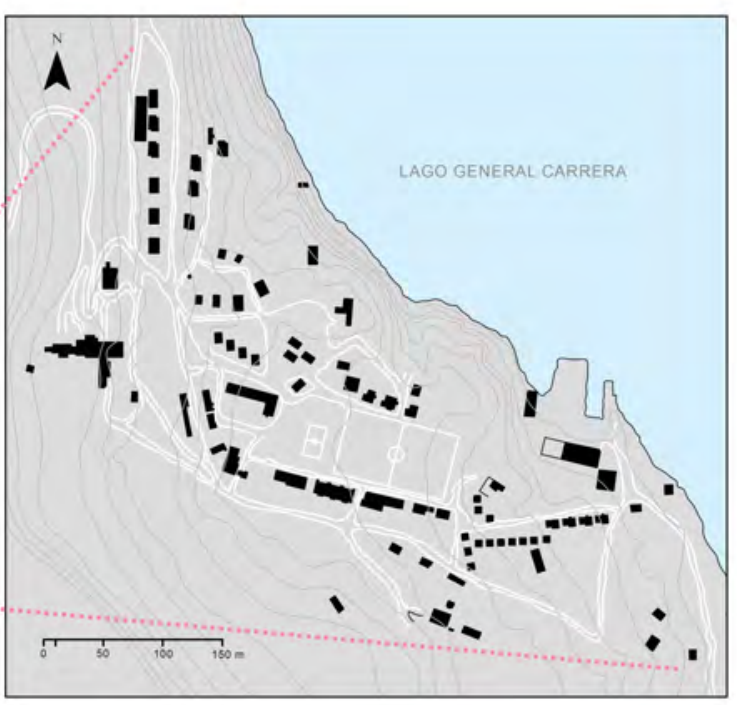

Fig. 2. Mapa de localización de Puerto Cristal, Puerto Ibáñez, región de Aysén. Fuente: Elaboración propia.

Hacia finales de la década de 1950, comienza un proceso de decadencia de la empresa. En un intento por revitalizarla, en 1964 se fusionó con la Compañía Carbonífera de Lota, surgiendo la Compañía Lota- Schwager S.A. Esta fue estatizada durante la Unidad Popular, pasando a manos de CORFO. Más tarde se fusionaron todas las empresas de la cuenca del carbón, formándose la Empresa Nacional del Carbón S.A. (ENACAR). La producción de carbón en Puchoco-Schwager se extendió hasta 1994. Después de una explosión de gas grisú en la cual murieron 21 trabajadores, se decidió cerrar la empresa, la cual ya había sido privatizada (Brito, 2018).

La producción minera en Puerto Cristal, a orillas del lago General Carrera (Fig. 2), comienza a mediados de la década de 1930, conocida como la Mina Silva, iniciando una explotación de carácter artesanal. Esto atrajo la atención del Estado, que bajo el liderazgo de la CORFO buscaba ampliar las zonas de explotación económica e industrial. El ingeniero Carlos Ruiz Füller realizó una prospección comprobando la presencia de zinc y plomo en Puerto Cristal, además de otros minerales como molibdeno, cobre, uranio, mármol y calizas. De esta manera se creó la Empresa Minera de Aysén-EMA, que en los años 40' comienza la explotación de zinc y plomo de alta ley, consolidándose un poblado minero, con la dotación de servicios para trabajadores y el equipamiento de producción industrial como una planta de concentración, un horno de fundición, bodegas, talleres, maestranza y muelle de embarque (Martinic, 2014). 
Puerto Cristal logró un desarrollo urbano en una extensión de veinte hectáreas, con viviendas para obreros y empleados con capacidad para 850 personas, con una serie de equipamientos urbanos, convirtiéndose en uno de los poblados con mayores instalaciones de servicios de la región (López \& Becerra, 2018). La producción minera se extendió hasta 1997, y a partir de esta fecha el poblado quedó deshabitado. Sin embargo, la mayor parte de las instalaciones se mantienen hasta hoy y están siendo recuperadas luego de haber sido declaradas Monumento Histórico Nacional en el 2008.

\section{FORMAS DE HABITAR EN LOS POBLADOS MINEROS}

Para comprender la producción del espacio social, realizamos un trabajo de recuperación de memorias con extrabajadores y sus familias, utilizando la estrategia metodológica de talleres con la técnica del mapeo colectivo. Esta última - según lo planteado por Ganter y colaboradores (2015) - es una técnica de investigación social cualitativa y participativa, que asume a los mapas participativos y de co-construcción colectiva, como un espacio intersubjetivo y ciudadano que posibilita la activación de la conversación social, el encuentro y la interacción con otros/as, con el propósito de intercambiar ideas, visiones y experiencias concretas sobre los territorios que se habitan, sus problemáticas, sus fortalezas, sus memorias, sus actualidades y su devenir; es una metodología narrativa que subvierte el lugar de enunciación convencional y lejos de trabajar con una mirada exclusivamente experta, busca sostener diálogos y sinergias constantes entre saberes diversos para producir datos y conocimiento no oficial, mezclando los relatos cotidianos de los habitantes, con la voz y la escucha atenta del saber especializado. Para el caso de Schwager se efectuaron 2 talleres en la sede de JJVV del Colectivo Chollín entre octubre y diciembre de 2014 (uno de mujeres, con 4 participantes; uno de hombres, con 5 participantes), además se realizaron 5 entrevistas en profundidad a extrabajadores de la carbonífera en el transcurso del año 2015. En Puerto Cristal se ejecutó un taller con la Agrupación Social y Cultural Los Cristalinos, en una casa particular en Chile Chico en enero de 2018, allí participaron 22 personas. Una vez realizados los talleres y entrevistas fueron transcritos y se sistematizaron en el software Atlas-Ti, definiendo tópicos que representaran las formas de habitar el espacio. Para este artículo trabajamos con 4 categorías: el asentamiento, el espacio social construido, la sociabilidad y el rol de las mujeres.

\section{El asentamiento}

Ambas instalaciones ocuparon en sus orígenes territorios no incorporados plenamente al desarrollo nacional. Aunque en temporalidades diferentes, fueron espacios de colonización, asociada a la expansión capitalista. Schwager en la zona de expansión de la segunda mitad del siglo XIX en los territorios mapuche, y Puerto Cristal, en una zona de colonización tardía del territorio austral, a comienzos del siglo XX. Las voces de quienes habitaron los lugares 
estudiados muestran las diferencias temporales. En la zona del carbón, el recuerdo de los orígenes se remonta a varias generaciones hacia atrás, en un discurso que se pierde en el tiempo, ya que no constituye un recuerdo nítido de sus propias experiencias. Parten con frases como 'por el conocimiento cuando los papás le conversaban a uno' y en los casos más concretos recuerdan que sus abuelos provenían del campo. En el caso de Puerto Cristal, suelen ser segundas generaciones. Sus padres fueron los que migraron entre los años $30 \mathrm{al}$ 50 y se instalaron en los territorios, en los que desarrollaron su vida laboral y familiar.

Lo más común en el relato es que las personas entrevistadas nacieron en las zonas industriales, formando comunidades cerradas, lo que permite construir una memoria social, a partir de experiencia en distintas fases de su vida en los asientos mineros. Tienen sus recuerdos de lo que significó ser hijos/as de trabajadores y habitar los territorios como niños/as, crecer y conocer a sus parejas y formar sus propias familias.

Mi papá trabajó 58 años de su vida. Yo nací en el pabellón 174 y me crié ahí y me casé a los 21 años, pololié 10 años con mi esposo. Desde los 11 años pololié con mi esposo y me casé a los 21 (Taller de Mujeres de Puchoco-Schwager).

...crecía en Puerto Cristal, cristalina neta. Mis padres llegaron de Ibáñez, y trabajaron cuando empezó recién la minera... Pero los mejores recuerdos los tengo en Puerto Cristal (Taller de Puerto Cristal).

El asentamiento definitivo se sustentó en el acceso a un salario (monetario y/o nomonetario) y en los beneficios a los cuales podían aspirar los trabajadores y sus familias. Se delinearon políticas de fidelización y reproducción de la mano de obra, a partir de prácticas de paternalismo industrial. En Puerto Cristal la instalación de la faena minera se dio en un contexto político en el cual las leyes del Estado regulaban las relaciones capitaltrabajo, aunque se reconoce que las dificultades del emplazamiento geográfico (aislamiento y la difícil conectividad) hicieron que la dependencia del empleador para la sobrevivencia fuese mayor, pues habían dificultades estructurales para un abastecimiento expedito, monetarizado y regulado por el mercado, fortaleciendo así las prácticas paternalistas. Por otro lado, en Schwager, en la primera etapa, existió nula regulación de las relaciones capitaltrabajo y ausencia del Estado como ente fiscalizador, lo que derivó en precariedad laboral y de vida. Esto trajo movilizaciones y organizaciones obreras en toda la zona del carbón, en busca de mejoras de las condiciones de vida. La respuesta fue primero la represión de la alianza Estado-empresario y después, la caridad cristiana y la filantropía, como una forma de frenar la politización del movimiento y la desestabilización productiva mediante las huelgas, sobre todo, después de la Huelga Larga de 1920 (Valenzuela, 2013; Benedetti, 2019). Se implementaron prácticas paternalistas que buscaron atraer, fijar y disciplinar la mano de obra, lo que implicó la construcción de una serie de equipamientos urbanos destinados al bienestar social de los trabajadores y sus familias. 


\section{El espacio social construido desde el paternalismo industrial}

La construcción de un espacio social en estos territorios implicó la construcción de una microsociedad, a partir de las relaciones sociales, las ideas, las imágenes y el conocimiento que colectivamente levantaron (Lindón, 2002). Uno de los aspectos centrales era lograr que se formaran comunidades, para lo cual se diseñó un tramado urbano que diese cabida a lugares de encuentro que fortalecieran la vida familiar y social. La comunidad -siguiendo a Delgado (2007)- puede definirse como una sociedad imaginada, caracterizada por la centralidad del parentesco y la vecindad, en donde sus miembros se conocen y construyen lazos de confianza, a partir del hecho que comparten la vida cotidiana y el trabajo. Todo lo cual tiene como contexto el territorio -el paisaje- al cual están adscritos y con el cual desarrollan una relación afectiva. De esta manera se fortalecía la construcción simbólica de pertenecer a una gran familia, como uno de los preceptos centrales del paternalismo industrial (Sierra, 1990).

Para lograr este objetivo las empresas generaron un conjunto de beneficios sociales. Uno de los aspectos más distintivos fueron los equipamientos, transformando a los lugares en autosustentados. Éstos pueden ser ordenados en 5 categorías: vivienda, escuelas, centros de salud, mercados y espacios de entretenimiento.

La vivienda fue fundamental para asegurar el asentamiento de familias. En ambas empresas se entregaron casas a los trabajadores casados ylugares de alojamientos colectivos para los trabajadores solteros. En el caso del carbón, las primeras habitaciones fueron los Pabellones (como en los otros centros carboníferos de la región), que se caracterizaban por ser casas unifamiliares, pero con servicios comunes (servicios higiénicos, hornos y lavaderos). Éstos subsistieron hasta bien entrado el siglo XX, pero en la actualidad han desaparecido. Los conjuntos habitacionales mineros que se mantienen hasta hoy son esencialmente dos: el Colectivo Chollín y el Conjunto Maule (Alarcón, 1996; Brieva, 2002; Fuentes \& Mayorga, 2012), ambos cuentan actualmente con protección patrimonial y permiten observar lo que fue el esplendor de la época del carbón. Se construyeron en la década de 1940 y representan zonas segregadas. Maule fue exclusivo para empleados y administradores, tiene una arquitectura mixta entre el neoclásico y la influencia inglesa neocolonial. Tenía equipamientos como el Casino Maule, que contaba con canchas de tenis, piscina, sala de billar, salón de baile, entre otros. También se encontraba en el lugar la Casa Schwager, que era una casa de huéspedes y donde se recibían las visitas ilustres. Además, hubo un kindergarten y un hospital (López \& Becerra, 2018). El otro conjunto es el Colectivo Chollín (Fig. 3), una construcción de gran envergadura y un fiel representante de la arquitectura moderna en nuestro país. Se construyeron bloques de departamentos, algunos unifamiliares y otros para solteros, en total se compone de 5 bloques habitacionales de 4 pisos, llegando a tener 176 departamentos unifamiliares y 20 para trabajadores solteros. Se agregó otro bloque que sirvió como casino para trabajadores solteros y allí funcionaba el Apostolado Popular, administrado por religiosas encargadas 
de la labor de formación cristiana, esencialmente con las mujeres. Este conjunto comienza a construirse en 1943 y fue un gran adelanto en las condiciones de vida de la clase trabajadora. En parte rompía con la fuerte segregación socio-espacial de los pabellones, ya que los primeros pisos eran habitados por empleados y técnicos y los pisos superiores por obreros. Contaban con calefacción central, alimentada por calderas que usaban el mismo carbón que se extraía de las minas como combustible y, además, cada vivienda unifamiliar contaba con baño propio (Díaz, 1962). El sector contaba con economato, retén de carabineros, mercado, plaza, iglesia, gimnasio, escuelas, cine y casinos (Fuentes, 2015; López \& Becerra, 2018).

En cuanto a Puerto Cristal, la minera también construyó equipamientos urbanos. Viviendas colectivas para obreros solteros y unifamiliares para obreros con familias (Fig. 4), contaban con mayores servicios, en comparación a la mayoría del territorio de Aysén habitado por trabajadores. Disponían de agua potable y alcantarillado, luz eléctrica y calefacción de leña. Además, existían casas para empleados con una construcción de mayor calidad, al igual que una casa de huéspedes. Los materiales de construcción fueron de mampostería de piedra y madera (López \& Becerra, 2018).

Las viviendas en ambos poblados eran de propiedad de las empresas y entregadas a los trabajadores mientras estaban contratados. Si eran despedidos o incluso si fallecían (aun en accidentes laborales que fueron frecuentes en las labores mineras) debía la familia abandonar las casas. Esto hacía que la permanencia de trabajadores por varias generaciones fuese una forma de mantener el lugar de residencia familiar

Tenía que entregar la casa. Si se moría, si salía el dueño de casa muerto de la mina la viuda se podía quedar 6 meses más viviendo o trabajando en la empresa (...) Así lo hizo mi suegra, se le murió el esposo que era minero y la pusieron a trabajar en el hospital de Maule y continuó viviendo en la casa (...) Pero si morían de enfermedad natural, tenían que dejar la casa, irse y entregar la casa (Taller de Mujeres de PuchocoSchwager).

En ambos territorios hubo escuelas, en el caso de Schwager fueron varias, para hijos e hijas de obreros, diferenciadas de las de empleados, además de una escuela industrial; en el caso de Puerto Cristal, con una población más reducida, sólo había una escuela que entregaba educación primaria. En ambos territorios los profesores/as, en una primera etapa, eran pagados directamente por las empresas.

En cuanto a los centros de salud, en Schwager se construyó un hospital y en Puerto Cristal existía una posta, en la cual había un "practicante" que daba solución a los problemas de atención primaria. La empresa se encargaba del traslado para casos de mayor complejidad. En relación a los centros de entretenimiento, la cancha es lo más recordado por los y las cristalinos/as y en Schwager son el cine, el teatro y los clubes deportivos. 


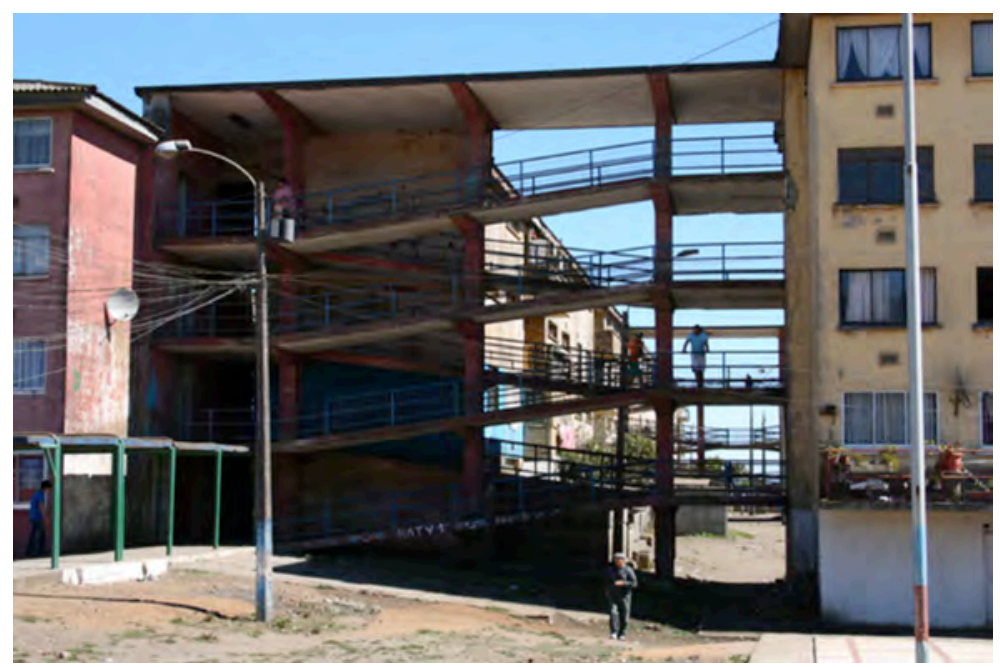

Fig. 3. Edificio Colectivo Chollín en Schwager.

Fuente: Archivo de Arquitectura, Universidad del Bío-Bío.

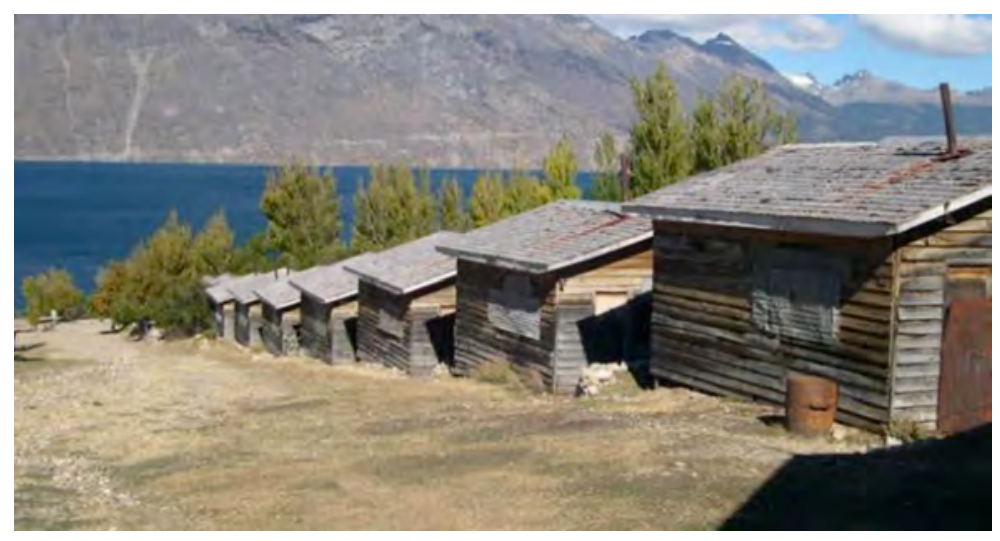

Fig. 4. Casas de trabajadores de Puerto Cristal. Fuente: Proyecto CONICYT- PIA Soc 1403.

Trabajo de terreno, enero 2018.

Para quienes habitaron estos asentamientos, los beneficios entregados por la empresa marcaron la diferencia en el bienestar alcanzado por sus familias. Aun en situaciones de precariedad y sin desconocer los niveles de explotación laboral, la posibilidad de contar con casa (aunque no fuese propia), escuela, atención de salud y abastecimiento cotidiano oportuno era muy valorada

(...) el mercado, había un molino donde vendían la harina tostada, había frutería, carnicería ahí adentro. Funcionaba todos los días, 7 días a la semana, se abría a las 9 de la mañana cuando vendían la leche también y se cerraba a las 8 de la noche, pero había de todo ahí, una fuente de soda adentro... Estaba la quinta compañía de bomberos y la cuarta, el teatro, acá teníamos muchas cosas. Era una ciudad chica (Taller de Mujeres de PuchocoSchwager). 
En lugares como Puerto Cristal, el contar con atención de salud en el territorio marcaba una diferencia, ya que el aislamiento y la ausencia de servicios públicos de fácil acceso transformaban a estos equipamientos en esenciales para la sobrevivencia

A mí me atendió don Abel Gamboa, y cuando yo tuve problemas de mi dentadura, que estuve grave... y lloraba, él me la sacó igual, ...Era practicante de todo, sí, todo. Muchas mujeres se atendieron esos años con él po'(...) la primera posta fue arriba (...) (Taller de Puerto Cristal).

Los servicios eran gratuitos, al igual que el mantenimiento de las viviendas, y fueron formas de salario indirecto; si se quebraban los vidrios los cambiaba la propia empresa, para la calefacción en Schwager entregaban carbón y en Puerto Cristal leña.

Se reconoce de manera negativa la segregación del espacio y el sentimiento de discriminación en el acceso a ciertos lugares, como los de entretenimiento. Aunque las empresas se esforzaban por generar los espacios adecuados para un ocio regulado por parte de los trabajadores y sus familias, éstos tenían una clara definición de clase, que se manifestaba de dos maneras: por un lado, en la construcción de espacios exclusivos para empleados y para obreros, como por ejemplo los casinos o clubes sociales (cuestión que se repite en ambas empresas); y, por otro, la diferenciación de clase en un mismo espacio, como sucedía en la zona del carbón con los cines y teatros.

En el cine había discriminación, abajo en platea había como 5 corridas más o menos de asientos con cadena a ambos lados. Esos asientos eran para los puros administradores y jefes de la empresa, nadie se podía sentar ahí. Nadie los podía tocar esos (Taller de Hombres de Puchoco-Schwager).

A pesar de la segregación social, la experiencia en el territorio es evaluada como positiva, siendo la construcción de una comunidad, lo más valorado. Existe conciencia de las experiencias comunes compartidas y los niveles de solidaridad, que los lleva a definirse como una verdadera familia, "los mejores recuerdos son de Puerto Cristal porque mi niñez fue linda, sana, nos conocíamos todos, era todo en comunidad, no como ahora que cada cual vive su metro cuadrado" (Taller de Puerto Cristal).

\section{La sociabilidad de los y las habitantes de los poblados}

Al ser comunidades cerradas, los espacios de sociabilidad internos fueron muy importantes, sobre todo aquellos construidos por las empresas. Para éstas, la creación de equipamiento para el entretenimiento de trabajadores y familiares fue central, con el fin de cumplir con los pilares del paternalismo (atraer - fijar - disciplinar). Para que el disciplinamiento 
fuese efectivo había que reeducar a los obreros y sus familias en un nuevo ethos cultural, para lo cual el ocio regulado era fundamental. En el caso del mundo del carbón, regular el ocio intentaba evitar que el obrero malgastara su dinero y su tiempo en actividades asociadas a la cantina y el burdel, que impedían una productividad adecuada (Alvarado, 2016); además, frenar la organización sindical que desafiara el orden patronal.

Los principales espacios de sociabilidad controlada por las empresas fueron equipamientos de uso colectivo: teatros, cines y gimnasios. Eran espacios donde se reunía la familia completa y el lugar privilegiado para la celebración de fechas importantes, tanto locales como nacionales (Día del Minero, Fiestas Patrias, Navidad, Año Nuevo). Allí las empresas podían prohibir o regular el consumo de alcohol y mantener una mayor vigilancia de los comportamientos colectivos. De acuerdo con el relato de los y las habitantes de los territorios, podemos distinguir tres momentos importantes en la sociabilidad: la fiesta, los lugares de encuentro y las prácticas transgresoras.

En cuanto a las fiestas, eran espacios de encuentros familiares y comunitarios, se hacían en los equipamientos construidos por la misma empresa o - como sucedía en Puerto Cristal - en casas dentro del recinto. Aquí se hace evidente las diferencias entre los dos casos estudiados ya que en Schwager las fiestas eran más e involucraban de manera directa a la compañía, la que ponía a disposición los espacios cerrados o abiertos y aportaba recursos. La empresa controlaba la venta de alcohol y vigilaba la seguridad. Estas fiestas eran organizadas por alguna de las instituciones que funcionaban dentro del barrio, como los bomberos

(...) fui 25 años bombero. Y cuando nos tocaba a nosotros hacer el baile, nosotros llevábamos coligüe, íbamos a buscar chocho, de todo, ramas. Para adornar bien adentro. Y como el alto tenía 9 metros más o menos donde pasaban los tirantes de los focos. Ahí paraban la escala y yo era el primero que me ganaba arriba para enganchar esas cuestiones (...) Adornábamos lindo el gimnasio (Taller de Hombres de Puchoco-Schwager).

La celebración de Navidad es recordada como una fiesta en la cual las distinciones de clase - tan marcadas en el recinto minero carbonífero - se diluían, lo que fortalecía el sentimiento de pertenecer todos a una misma familia, aumentando de esta manera los lazos comunitarios

Lo bueno que había aquí en el gimnasio, lo bueno era que todos éramos niños no importaba que el papá fuera empleado o no fuera. Los juguetes para la pascua en el gimnasio, nos sentábamos en el gimnasio y pasaba el viejito pascuero y nos daban confites, galletas, naranjas (...) (Taller de Hombres de Puchoco-Schwager).

Otra de las actividades más recordadas y que se celebraron en los años de mayor esplendor de la explotación del carbón fueron las Fiestas de la Primavera, en las que se organizaban 
comparsas y carros alegóricos, se elegían reinas y se reunía a toda la comunidad. Los carros desfilaban por todos los espacios públicos, adornados temáticamente. La planificación de la fiesta era una actividad muy importante y se formaba un Comité Ejecutivo y comisiones para su organización. Se hacían desde comienzos del siglo XX. Según el periódico La Información (órgano empresarial), para las fiestas de 1938 se nombraron comisiones de: propaganda y programa, elección de reina, escrutadora de sufragios, bailes, recepciones, velada bufa, corso, comparsas, afiches, prólogo y cantos, música. El Departamento de Bienestar era el encargado de coordinar todas las actividades y los fondos reunidos (mayoritariamente por los votos vendidos por las candidatas a reina) estaban destinados a financiar las colonias de verano para los niños y niñas. La compañía proporcionaba gratuitamente el teatro de Puchoco, camiones para comparsas, locales y materiales para locales de baile. La celebración duraba 11 días, en los cuales se hacían variadas actividades y terminaba un domingo en la noche con un baile popular ${ }^{3}$.

En Puerto Cristal las fiestas más significativas que se guardan en la memoria eran el Día del Minero en agosto de cada año, el Día del Trabajador y las Fiestas Patrias. Recuerdan que "Eran muy hermosas... Como de familia... Se bailaba..." (Taller de Puerto Cristal).

A pesar de las diferencias entre los dos territorios, sobre todo en el despliegue de recursos de las empresas, para los exmineros y sus respectivos grupos familiares representaban un espacio de encuentro, que los hacía abstraerse de las duras condiciones de vida y les permitía entregar a sus familias la entretención que, en el caso de Puerto Cristal, era mucho más escasa, debido al aislamiento geográfico que implicaba la vida en el campamento.

Los lugares de encuentro estaban asociados a espacios naturales que circundaban los asientos mineros, incluían los paseos familiares y picnics a los cerros o playas. Quienes habitaron en Puerto Cristal hacen referencia a la Piedra Negra, espacio natural a orillas del lago y donde pasaba un río. Esta gran piedra era un lugar de esparcimiento de jóvenes. También se refieren a éste como un espacio para los encuentros de parejas que se iban constituyendo entre los jóvenes del mismo territorio.

En Schwager se destacan las actividades de los fines de semana que reunían a toda la familia, como la banda instrumental que recorría el lugar los domingos. Allí se podían ver a los "mineros que uno veía todos cochinos los días de semana, ... los veía encorbataditos todos, con zapatos lustrados" (Taller de Hombres de Puchoco-Schwager). Otro espacio de encuentro familiar eran las competencias deportivas. Recuerdan el estadio construido por la empresa como un lugar significativo donde se hacían campeonatos entre las distintas empresas de la región

Nosotros éramos hartos hermanos y mi mamá con un canasto grande, íbamos todos. Éramos 9 hermanos, más los familiares hermanos de ellos, los primos. Mis papás con sus hermanos $(\ldots)$ 
En esos años el día domingo se llenaba los estadios, eso era lo entretenido, la gente, los viejos, al menos yo me acuerdo que iba con mi papá y nos llevaban a nosotros al estadio (Taller de Hombres de Puchoco-Schwager).

En el caso de los habitantes de Puerto Cristal la extensión territorial era muy vasta; sin embargo, los principales lugares de encuentro estaban asociados al equipamiento del lugar y así recuerdan como significativo las canchas que eran

(...) un lugar de toda la familia. Los jóvenes en la tarde...Y uno pololeaba por aquí por la orilla... Yo creo que la cancha de básquetbol y la cancha de fútbol era donde nos juntábamos más, porque eran hombres, mujeres y niños (...) nosotros íbamos a jugar por ejemplo a la cancha de básquetbol... porque ahí había iluminaria, uno ahí podía jugar hasta las 12 las 1, siempre se jugaba por ejemplo los sábados, en esa cancha había luz pu', había galerías (...) Era como la plaza... pero nosotros íbamos a jugar y se llenaba... [porque] las luces prendías (sic), quedaban toda la noche (Taller de Puerto Cristal).

En ambos espacios había vigilancia y se aplicaban prácticas de control social destinadas a mantener la armonía social, resguardando la propiedad de las empresas. Esto los facultaba para imponer reglas que evitaran los conflictos y que permitieran mantener la productividad. En este aspecto una de las cuestiones que aparece en ambas experiencias es el establecimiento de zonas secas, es decir, la prohibición del consumo y venta de alcohol en el recinto industrial. En el caso de Schwager se hicieron desde muy temprano campañas antialcoholes, las cuales eran coordinadas por las visitadoras sociales, a fin de prevenir el ausentismo laboral y los accidentes laborales (Godoy, 2015; Alvarado, 2016; Brito \& Contreras, 2018). Sin embargo, estas políticas nunca fueron lo suficientemente eficientes para erradicar el consumo en los mineros, quienes se las arreglaban para ingresar clandestinamente bebidas al interior de los recintos.

En el caso de Schwager la posibilidad de transgredir las normas era más fácil, en la población La Colonia, cercana al recinto industrial (habitada también por familias mineras, que no tuvieron acceso a las viviendas de la empresa o que vivían indirectamente de la actividad minera, al entregar servicios a los trabajadores), se instalaron cantinas y burdeles, lugares que no sólo se utilizaron para transgredir las normas morales establecidas por la empresa, sino que además fueron usados como lugares de transgresión política (hacían reuniones sindicales o se planificaban protestas laborales). En Puerto Cristal, también circulaba el alcohol de manera clandestina, llegaba gente a caballo desde Puerto Ibáñez a venderlo.

\section{Las mujeres en los poblados mineros}

Los poblados mineros privilegiaron el asentamiento de familias, garantizando una mayor estabilidad de la mano de obra, además de desligarse de su reproducción, transformando en 
plusvalía el trabajo no remunerado de las mujeres asociadas al núcleo familiar. El trabajo femenino fue concebido como un no lugar en la economía capitalista, "desligada de lo social, como si fuese algo independiente, eludiendo así toda responsabilidad sobre las condiciones de vida de las personas" (Carrasco, 2009, p. 175). El análisis de las dos esferas en la vida de las mujeres (trabajo y cuidados) se constituye en una cuestión central para comprender el modelo industrializador. Con el capitalismo liberal, cambian los patrones de relaciones y de consumo, definiéndose la ideología de la domesticidad y a las mujeres como cuidadoras naturales, generando conflicto entre la maternidad y las actividades productivas (Carrasco, Borderías \& Torns, 2011).

Así, la principal función de una mujer en los centros mineros era la de dueña de casa, encargada del cuidado del esposo y de los hijos e hijas. La mayoría no trabajaba remuneradamente fuera del hogar. En Schwager algunos hombres afirmaban que las mujeres eran 'dueñas de casa no mas'. El trabajo doméstico implicaba, por una parte, atender al marido cuando se iba y cuando volvía de la mina, lo que incorporaba una serie de rituales, como el 'caldito mañanero' (caldo que todos los días daban al esposo antes de ir a la mina) y, al volver, el 'harinao' (vino con harina tostada), que según sus creencias les limpiaba el polvillo que inhalaban al interior de la mina.

Hay dos espacios femeninos en la zona del carbón que se relevan en la memoria, uno es el horno y el otro el lavadero. Los hornos eran de uso exclusivo de las mujeres y era mal visto que los hombres los utilizaran. Se reconocía como un espacio de mujeres, que requería una organización previa, sobre todo quién debía hacer la 'primera caldea', que implicaba prender el horno y calentarlo. Los turnos se respetaban, haciendo eficiente el uso de este bien colectivo

Todos lo podían ocupar poniendo su numeración, se respetaba el orden... [Se juntaban]entre vecinas, dependía de la necesidad. Porque podía ser una señora de aquí de la esquina con una de los colectivos, pero la cosa era llevar la leña, quemarla y cocer el pan. Y cada persona reconocía su pan por una marca que se le hacía... Hasta 50, 60 panes. Todo así bien puesto, habían unas expertas que eran una bala para poner el pan (Taller de Mujeres de Puchoco-Schwager).

El otro espacio valorado por las mujeres eran los lavaderos colectivos, ya que era un lugar donde se lavaba a escobilla, pero que tenía la ventaja de contar con agua caliente y secadores de ropa, para lo cual se usaba el mismo carbón de piedra de las minas. Esto fue considerado como una gran ventaja del recinto, porque incluso podía ser utilizado por las familias que no vivían en las casas de la compañía. Una señora recuerda que ella vivía en La Colonia y acompañaba a su madre a los lavaderos

Yo [vivía] en La Colonia... Donde está el jardín infantil ahora, había antes un lavadero y mi mamá venía a lavar. Yo era chica y venía con ella... Yo a veces me perdía y 


\section{A. BRIto}

me metía adentro de los secadores y estaba ahí muy sentada dentro, su buen rato, bien oscuro. Muy sentada, como estaban calentitos adentro. Eran como dos fierros, así dos tubos largos y llevaban una puerta con un gancho y uno los abría para atrás hasta bien atrás. Y ahí se colgaba las ropas (Taller de Mujeres de Puchoco-Schwager).

En Puerto Cristal las mujeres en su mayoría también eran dueñas de casa, dedicadas al trabajo doméstico y al cuidado de la familia. A diferencia del mundo del carbón no existieron espacios colectivos para labores domésticas, pero se relevan ciertas particularidades como el lavado de ropa que se hacía en tinas construidas de barriles de vino (cada una lo hacía en su casa, pero utilizando métodos similares)

En esos años salía el vino en barriles, entonces cuando habían barriles que no se ocupaban se cortaba por la mitad y se hacía una tina... Y su tabla y su fuego afuera para calentar el agua...Nos bañábamos en esas tinas, yo me acuerdo, si era una tina, nos ponían agua calentita y nos metíamos ahí. Eran con unos fierros así a los lados... Así como una tinaja (Taller de Puerto Cristal).

El trabajo remunerado para las mujeres en los recintos mineros era escaso. Sin embargo, en ambas experiencias encontramos mujeres que trabajaron en áreas de servicios. En Schwager se las reconoce en labores profesionales como las visitadoras sociales, enfermeras, matronas y profesoras, además de cargos administrativos como secretarias o dependientas en los economatos. En el caso de Puerto Cristal, la única mención que hay de mujeres profesionales es de algunas profesoras, que eran pagadas por la misma empresa. Pero sí trabajaron en actividades administrativas o de servicios. Una cristalina nos relata

(...) estuve toda mi niñez, mi juventud, mis hijitos allá, del año 51 al 94, sin salir de allá, solamente a hacer diligencias, y trabajé también en la casa de huéspedes, una que está arriba del cerro ahí, trabajé también en las oficinas abajo como junior, trabajé en la radio como operadora, y así varias, y anteriormente había trabajado en casino así como ayudanta de las personas y asesora del hogar en varias casas, porque allá lo único que se trabajaba era eso (Taller de Puerto Cristal).

Tal como nos relataron en ambos poblados, una opción laboral para esposas o hijas de obreros fue el servicio doméstico en casa de empleados, “(...) mi mamá que iba a trabajar. Igual trabajaba, igual venía a trabajar con todos los hijos, para acá a Schwager, venía a lavar, venía a ayudar al Recinto" (Taller de Mujeres de Puchoco-Schwager).

En ambas empresas se procuró generar actividades para mujeres, dando cursos de manualidades, fortaleciendo así el carácter doméstico de las mismas. Con algunas diferencias, en la zona del carbón existió tempranamente un interés por formar a las mujeres para 
convertirlas en buenas madres y esposas, para lo cual se crearon organizaciones, como fue la Sociedad femenina Carolina Schwager. Allí se hacían cursos de costuras, lencería y, en general, lo que se definía como trabajos de mujer

Allí van hijas de obreros a adquirir conocimientos que han de hacerlas dignas hijas, esposas y madres del mañana. Apoyada esta entidad por los jefes de este mineral va cada día progresando más siendo dirijida (sic) por un Directorio que no omite sacrificios para cumplir con las aspiraciones altruistas de la compañía en bien de sus obreros y familia ${ }^{4}$.

En estas organizaciones, además, se entregaba formación moral y cristiana, usando a las mujeres como vía para transmitir el discurso moralizador de las empresas. Con el paso de los años el trabajo de formación de las mujeres se mantuvo y en los relatos recogidos se reunían en el Apostolado Popular. Allí se "enseñaba a bordar, a coser, a tejer, eso era por monjitas... Ese era el apostolado... El centro de madres era el apostolado" (Taller de Mujeres de Schwager).

En el caso de Puerto Cristal tuvieron la posibilidad de asistir a cursos que les permitían realizar actividades útiles para el hogar y que incluso también podían generar algunos ingresos. Según el relato, fueron más bien acciones autogestionadas donde la que sabía hacer alguna manualidad se la enseñaba a las otras; así formaron Centros de Madres. A diferencia de lo que pasaba en Schwager, donde las actividades eran más dirigidas desde arriba y controladas principalmente por las visitadoras sociales, en Puerto Cristal no existió esta profesional; pero algunas de sus funciones fueron realizadas por las esposas de los administradores del recinto minero. Además, en época de dictadura, mencionan que enviaban monitoras de CEMA Chile a hacer cursos. Recuerdan a la esposa de un administrador que les enseñaba labores manuales en los centros de madres

(...) la señora Inés Cuello que le enseñó a ellas. Ella fue la que enseñó a pintar... Yo supe zurcir con pelo, por esa señora... Y ella nos enseñaba, bueno las mamás, las mayores le enseñaban a sus hijos, bueno yo trabajé años en el centro de madres (Taller de Puerto Cristal).

Estas actividades les posibilitaban reunir dinero para sus familias ya que vendían lo que hacían. Esto constituye una parte importante del recuerdo ya que con estas acciones reunían fondos para las fiestas de fin de año, especialmente para Navidad

ahí empezábamos a trabajar y a fin de año nosotros le comprábamos a todos nuestros hijos una tenida pa' la Navidad. Además, compartían entre las familias 


\section{A. BRIto}

después compartíamos todas las... las esposas y las... las señoras, o sea los maridos, toda la familia, una cena, unos asados, bailábamos (Taller de Puerto Cristal).

Esto fortalecía los lazos entre las mujeres. Por otro lado, estos aprendizajes son utilizados por algunas hasta el día de hoy, como una forma de aumentar los ingresos familiares.

Un último aspecto que relatan las mujeres de los dos recintos mineros fue la violencia doméstica, reconocida en ambos territorios como una práctica habitual, aunque manejada de manera diferente. En el mundo del carbón se reconocía el machismo de los mineros, que sentían que las mujeres eran de su propiedad, lo que ha sido interpretado como parte de la identidad masculina minera, a la cual se agregaba el alto índice de consumo de alcohol

(...) los papás antes se iban a las bodegas y ahí se juntaban con todos los otros mineros...Y ahí se peleaban así “oye tu andaí coqueteando...”... y ahí llegaban con la mañana y le pegaban a la señora, que tonteras hablaban entre ellos, le decían que la señora lo gorreaba y la pobre mujer no tenía tiempo ni para ella y iba a salir a gorrear con tantos hijos. Entonces a los hombres con copete le entraba eso a la mente y le pegaba a la señora y le sacaba la remugre a la pobre (Taller de Mujeres de Puchoco-Schwager).

A pesar de esa realidad, las mujeres de los recintos carboníferos encontraron en la visitadora social, una aliada para combatir la violencia doméstica que sufrían. De hecho, consideraban que tenía mucho poder y la usaron como estrategia para frenar las actitudes violentas de sus parejas, ya que los amenazaban, "ah bueno, tendré que ir a hablar con la visitadora... así obedecían, era como ahora denunciar a carabineros” (Taller de Mujeres de Puchoco-Schwager).

En Puerto Cristal, al no existir una visitadora social, la violencia doméstica se vivía de manera más silenciosa, vivenciada en los espacios privados. No había dónde denunciar, porque los carabineros que existían en el recinto - como en otros lugares del país - consideraban que esto era una cuestión privada, donde el Estado no debía intervenir. En muchas ocasiones justificaban las actitudes de los esposos y les aconsejaban a las mujeres no provocar al marido, legitimando la existencia de violencia

Se la guardaba nomás, si le pegaba, calladita nomás... Le podían haber sacado la cresta a uno quien iba, íbamos a los carabineros "vaya a su casa si su marido le pegó", así decían antes... Todos calladitos nomás, llorábamos las lágrimas. Sí, si así fue... Que aparte antes no era lo mismo cuando tenías los niños chicos, que para la mujer yo creo que era mucho más difícil (Taller de Puerto Cristal). 


\section{EL IMPACTO DEL CIERRE DE LAS MINERAS}

La vida en el campamento minero de Puerto Cristal es recordada positivamente, considerando el acceso a equipamiento urbano y una vida comunitaria y tranquila. Aunque existe conciencia que muchas veces la vida fue precaria, los salarios eran bajos y algunos productos podían escasear por el aislamiento geográfico, hay una valoración altamente positiva del lugar. Esto se fundamenta en la comparación con el resto de la región, donde muchos de los servicios con los que ellos contaban en el campamento, como iluminación pública las 24 horas, servicios higiénicos al interior de las casas, agua caliente, entre otros, eran desconocidos en algunos territorios circundantes y sólo eran habituales en las ciudades más grandes de la región. Esto hizo que cuando tuvieron que alejarse del territorio el impacto fuese mayor

(...) yo cuando me casé acá yo lloraba, porque yo cuando me casé me vine a la casa de mi abuelita y acá en ese tiempo había pozo negro que le llaman, al baño afuera de la casa, y mi abuelita tenía un sitio y al final ella hizo lejos pa' allá, y en la noche oscura, un miedo. Y yo lloraba porque yo allá en mi casa tenía esa comodidad que me había criado con el baño adentro, y aquí cuando llegué acá a Chile Chico no, cortaban la luz ... a las 12 y el día sábado a las 1, o sea era un cambio. Allá tenía agua caliente, acá ni siquiera había agua caliente en esos años (Taller de Puerto Cristal).

Para los habitantes de Schwager la etapa de cierre del ciclo paternalista industrial fue un proceso más largo. La empresa se había fusionado con la minera de Lota en 1964 y luego estatizada con el gobierno de la Unidad Popular, pasando a formar parte de ENACAR. Con la dictadura militar y la instalación del modelo neoliberal, comienza un proceso de privatización. En 1979 pasa a ser filial de ENACAR. En 1986 se convirtió en sociedad anónima abierta, para privatizarse completamente en 1989 (Brito, 2018). Aquí se produce un primer impacto, porque se acaban las políticas paternalistas, debiendo, por ejemplo, comenzar a pagar los servicios básicos.

Cuando la compañía minera de Puerto Cristal cerró, la impresión de sus trabajadores y familias fue de mucho desconcierto y en cierta medida de desamparo, como nos manifiestan: "Fue triste cuando nos tuvimos que ir... porque hay un desarraigo, de pronto te sacan de un lugar de una forma tan abrupta que uno no termina de entender lo que pasa" (Taller de Puerto Cristal). En general migraron dentro de la propia región, donde las posibilidades laborales eran difíciles, lo cual fortaleció el imaginario de las comodidades en las cuales habían vivido. La empresa cierra sus funciones en 1997 y todos los trabajadores son despedidos. El pago de las indemnizaciones fue negociado

De acuerdo al relato fue la intervención de Antonio Horvath, quien era senador por la región de Aysén en el período de cierre de la minera, la que posibilitó el pago de las indemnizaciones. 
políticamente ${ }^{5} \mathrm{y}$, aunque los salarios eran bajos (de acuerdo al relato apenas si alcanzaba el salario mínimo, que en 1996 era de \$65.500), aquéllas les sirvieron para instalarse en otros lugares de la región. Una de las cosas que se recuerda es que les dieron la posibilidad de comprar las casas en las cuales habitaban, pero a diferencia de Schwager, esto no significaba que pudiesen quedarse a vivir en el territorio, sino más bien que las casas las podían desarmar y trasladar a otros lugares para rearmarlas.

En Schwager, aunque el cierre de la producción de carbón se veía venir, la decisión final fue a partir de un incidente trágico, la muerte de 21 mineros producto de la explosión de gas grisú en el pique Arenas Blancas el 30 de septiembre de 1994. Este accidente provocó la toma del pique por 12 días y llevó al cierre definitivo.

Los trabajadores y sus familias quedaron con un sentimiento de incertidumbre en relación a su futuro, nos dicen: "estamos a la deriva”, “somos unos pobladores más nomás”, "lo de la empresa quedó harto atrás”. En ese momento se tomó conciencia que, aunque el trabajo era duro y riesgoso, era algo seguro

un sentimiento generalizado que decía 'al fin nosotros no vamos a tener que meternos más a este hoyo’ porque era un sacrificio, colocarse el casco, meterse al hoyo $y$ ir al sitio del trabajo era un sacrificio y la gente en el fondo no le gustaba la mina, tenía que trabajar para ganarse el sustento... Pero el minero siempre echaba de menos, a pesar de todo lo que se pasó ...hay mucha gente que todavía echa de menos la mina y sueñan con la mina. ¿Qué pasa con eso? Quedó ahí, quedó arraigado, está ahí metido (Entrevista a un exminero de Puchoco-Schwager).

Después del accidente y la posterior toma de la mina, se llegó a un acuerdo con la empresa y se entregó una pensión a los trabajadores y lograron que les vendieran sus casas. Esta experiencia histórica compartida hizo que se forjara una mayor cohesión social ya que todos los habitantes se sentían parte de una misma comunidad laboral y social. Además, estaban sometidos a la misma disciplina, lo que derivaba en un desarrollo y vinculación con el espacio regulado y reproducido culturalmente desde los mismos espacios cotidianos, "porque todos trabajaban en lo mismo. Había más solidaridad. Claro que hay diferencias, antes había más participación en cuanto a lo cultural” (Entrevista a un exminero de Puchoco-Schwager).

En Puerto Cristal la fuerte identidad forjada en el territorio hizo que se reagruparan en una organización llamada Agrupación Social y Cultural Los Cristalinos, que tiene su sede en Chile Chico y está formada mayoritariamente por mujeres, quienes se unieron con el objetivo de ir al lugar a limpiar el cementerio. Esto conforma un espacio simbólicamente muy importante, porque en la práctica se constituye como un sitio de memoria, porque allí están sus seres queridos, sus propias historias familiares, las cuales no pueden - ni quieren - olvidar. El primer año que volvieron al poblado fue en 2004 y recuerdan 
Fuimos como 30 personas y ahí fui yo, fui con mis dos hijos, yo quería que mis hijos conozcan, tenían como... 7-8 años más o menos, y nos quedamos en la casa de administración. Ahí vimos cómo estaba Cristal, cómo estaba el cementerio y cuando volvimos nosotros ahí le contamos a la gente, a todo' y de ahí decidimos formar la agrupación con ese fin po', de sobre todo del cementerio, porque el cementerio estaba pero perdido en matorrales... No se podía entrar, era un solo bosque (Taller de Puerto Cristal).

A partir de entonces viajan todos los años a Puerto Cristal realizando un encuentro, en el cual limpian el cementerio, celebran el Día del Minero y reviven el sentido comunitario que tenían cuando residían en el poblado

(...) tratamos de hacer muchas actividades en un solo día, y que yo creo que a cada uno le llena mucho eso, por eso trabajamos... yo lo que digo es que voy a cargar energías para pasar todo el resto del año acá po', para realizar mi vida, porque irte a llenar con todos los recuerdos todo lo que pasaste ahí de tu niñez de tu juventud o sea son..., para mí son cosas invalorables (Taller de Puerto Cristal).

En Schwager, hay un sentimiento de pérdida de identidad asociada a la destrucción de los espacios que marcaron su experiencia cotidiana y el orgullo de ser minero, a lo cual se suma la crisis económica y ecológica que ha vivido la comuna con el cierre de la actividad carbonífera, con altos índices de cesantía, problemas de contaminación asociados a la instalación de empresas pesqueras y eléctricas. En los últimos años, ha habido un proceso de toma de conciencia de la importancia territorial, asociada a la preservación del patrimonio industrial, generando instancias de organización y participación social que visibilizan la experiencia vivida en Schwager. En la actualidad están en funcionamiento las siguientes organizaciones: Schwager por siempre, Guías Patrimoniales de Puchoco, Agrupación de Amasanderas de Puchoco-Schwager, además de las Juntas de Vecinos Nº11 y Raíces del carbón.

\section{REFLEXIONES FINALES}

En la tabla que presentamos a continuación podemos observar la síntesis comparativa de las formas de habitar en los poblados mineros estudiados, en los cuales se marcan las similitudes y las diferencias.

En Schwager hay un recuerdo un tanto mitificado de la experiencia vivida, lo que está en directa relación con las experiencias post cierre de las faenas (depresión económica y falta de empleos). La identidad minera, no reconocida por los agentes del Estado, hizo difícil que los planes de reconversión dieran frutos en el corto y mediano plazo (Lavoz \& Shejade, 2010; Brito, 2018). La creación de nuevas fuentes productivas, como las empresas pesqueras, 


\section{A. BRITO}

Tabla 1. Síntesis de comparación entre Schwager y Puerto Cristal.

\begin{tabular}{|c|c|c|c|}
\hline \multirow[t]{2}{*}{ Categorías } & \multirow[t]{2}{*}{ Similitudes } & \multicolumn{2}{|c|}{ Diferencias } \\
\hline & & Schwager & Puerto Cristal \\
\hline \multirow[t]{2}{*}{ Orígenes } & Zona de Colonización & $\begin{array}{l}\text { Surge dentro del modelo de desarrollo } \\
\text { liberal del siglo XIX, con ausencia del } \\
\text { Estado como ente regulador de las } \\
\text { relaciones entre capital y trabajo. }\end{array}$ & $\begin{array}{l}\text { Consolidación de } \\
\text { explotación minera dentro } \\
\text { del modelo de desarrollo de } \\
\text { la ISI, con fomento desde la } \\
\text { CORFO. }\end{array}$ \\
\hline & $\begin{array}{l}\text { Reproducción de la mano de obra. } \\
\text { Más de una generación. }\end{array}$ & $\begin{array}{l}\text { Diferencia de temporalidades en los y } \\
\text { las entrevistadas: } 3^{\mathrm{a}} \text { o } 4^{\mathrm{a}} \text { generación. }\end{array}$ & $\begin{array}{l}\text { la mayoría son } 2^{\mathrm{a}} \\
\text { generación. }\end{array}$ \\
\hline
\end{tabular}

Inmersos en prácticas de paternalismo industrial: bienestar y control social.

Existencia de un Departamento u Oficina de Bienestar que resolvía los Equipamiento problemas de los habitantes. Urbano

Todo el equipamiento, incluyendo las viviendas eran de propiedad de las empresas, hasta el término de las faenas.
Se otorgaron facilidades para la compra de las viviendas, posibilitando que el barrio continuara.
Les dieron la posibilidad de comprar las casas, las que eran desarmadas y trasladadas a otros lugares. Por lo que el barrio se disuelve.

\section{Valoración positiva de la comunidad \\ Comunidades cerradas: sociabilidad hacia adentro}

Sociabilidad

\section{Importancia de las Fiestas como} expresión comunitaria.
La empresa destinaba recursos para su realización, además de facilitar los espacios.

Más importantes: Fiesta de la Primavera y Navidad.

Hubo inserción laboral de mujeres profesionales: visitadoras sociales, matronas, enfermeras y profesoras. de casa.

Espacios de formación del rol esperado

Rol de las mujeres
Existencia de violencia doméstica. Asociada al machismo que se concibe como propio de la masculinidad minera.
Se realizaba desde arriba, como expresión de control social, dirigido por la misma empresa o por congregaciones religiosas en el Apostolado Popular.

Existió una mayor red de apoyo en relación a la violencia doméstica, cumpliendo la visitadora social, un rol preponderante, tanto en la prevención, como en el tratamiento del problema.
Más autogestionadas.

Más importantes: Día del Minero, $\operatorname{los} 1^{\circ}$ de mayo.

Sólo hubo profesoras.

Era un espacio autogestionado y que en algunos momentos contó con el apoyo de CEMA Chile.

Se vivió de manera más individual, con menos redes de apoyo.

Algunas se insertaban en el mercado de trabajo más informal como empleadas domésticas en casa de empleados. 
el Puerto de Coronel y más recientemente las termoeléctricas, transformaron a Coronel en una zona de sacrificio, lo cual ha dificultado la redefinición de las identidades locales. En el caso de Puerto Cristal, la memoria está marcada por el cierre de lo que fue un tiempo y una experiencia de vida, en la cual contaban con más acceso a servicios, pero hay conciencia que los procesos no tienen muchas posibilidades de vuelta atrás y la migración de su población a distintos lugares de la región o del país fortalece la idea de una memoria patrimonializada, que recupera casi en un sentido museístico su experiencia como cristalinos. En cambio, los extrabajadores del carbón aún deambulan por el territorio en la búsqueda de un sentido en aquél, como espacio productivo y como constructor de identidad social.

Puerto Cristal fue declarado Monumento Histórico Nacional en 2008, pero hoy se encuentra deshabitado, en la práctica es un museo en sí mismo, que cobra valor cuando se visita, cuando se recorren sus calles y sus casas que alguna vez albergaron una importante población. En cambio, en Schwager, las condiciones de habitabilidad han sido mejoradas en distintos planes gubernamentales, como el Programa de Recuperación de Barrios, en el que se trabajó con los vecinos/as durante el 2008. Sin embargo, el vestigio del esplendor del pasado minero ha ido paulatinamente desapareciendo; hoy sólo quedan ruinas. En el año 2010 se logró llevar a cabo la Declaratoria de Zona Típica por el Consejo de Monumentos, lo que posibilitó atraer recursos de los planes de recuperación de barrios patrimoniales post terremoto de 2010. Y aunque un porcentaje de su población insiste en mantener su memoria sobre el pasado minero, otros apenas si la recuerdan y no se sienten interpelados por las demandas por el resguardo patrimonial.

Este es un aspecto central que diferencia a los dos territorios. En Puerto Cristal, el recinto minero se mantiene como una ruina monumental, que puede ir tomando un carácter museístico a partir de la Declaratoria de Monumento, lo que refuerza el sentido simbólico del lugar. Existe posibilidad de mantenerlo, de resguardarlo, aunque tenga un dueño, el que se ha sumado también al esfuerzo de darle un valor patrimonial, al incorporarlo a los circuitos turísticos de la región de Aysén ${ }^{6}$. Se observa una diferencia central en el hecho de no vivir en el espacio y visitarlo y el de habitar de manera permanente en el lugar. En el primer caso, al no vivir y visitarlo se le otorga un sentido a su existencia en la medida que la memoria de sus exhabitantes se renueva en cada visita, actuando como activadores patrimoniales, tal como lo señala Prats, quien afirma que los "patrimonios realmente existentes son repertorios activados de referentes patrimoniales ... Estos repertorios son activados (en principio) por versiones ideológicas de la identidad" (2000, p. 121). Esto significa que los excristalinos se constituyen en patrimonio vivo, trascendiendo la materialidad, otorgándole un contenido al sitio, al incorporarle sus vivencias, transformándolo en un territorio social en el cual confluyen las distintas significaciones del espacio. Siguiendo a Lefebvre (2013), los excristalinos reconocen el valor del espacio material, la representación que de él construyen ellos mismos y los otros y, por sobre todo, reconocen su propia experiencia en el territorio dándole significación patrimonial.

\footnotetext{
Bernardo Casanova es quien administra el sitio y hace recorrido turístico, ver www.turismopuertocristal.cl
} 
En el caso de Schwager, paradojalmente, el seguir viviendo en el espacio y ser observador de su destrucción y la pérdida de memoria colectiva (a pesar de los intentos por mantenerla de las organizaciones patrimoniales existentes), hace que la búsqueda del sentido patrimonial choque con la realidad actual, que ha convertido a la comuna de Coronel en una zona con altos índices de cesantía, delincuencia, violencia y devastación ecológica. Ya que no sólo se ha perdido el paisaje industrial que le dio sentido al poblado, sino también el paisaje natural, que permitió construir una relación más armónica con el entorno, haciendo que los límites del esparcimiento natural incluyeran la playa, los cerros, los bosques, etc. Todo ello reforzaba una identidad industrial y territorial. Hoy es una zona con altos índices de contaminación y que, por lo tanto, expulsa a su propia población. La lucha de sus habitantes necesariamente excede la búsqueda del resguardo del patrimonio industrial y lo que se anhela es una mejor calidad de vida, lo que refuerza el sentido nostálgico del pasado industrial, ya que aun con las precariedades e inseguridades que la mina generaba, era posible sostener una calidad de vida aceptable.

Esto hace que cobre sentido la idea planteada por Dormaels (2011) para quien el patrimonio es una relación mediática entre el objeto soporte y las personas. El patrimonio tiene significados e interpretaciones y por lo tanto se reactualiza y permite que se constituya como tal. Este punto es muy importante porque en Puerto Cristal, aun cuando el pueblo o la mina no funcionan, existe una significación y una interpretación del lugar, dándole existencia. Se revitaliza y se reactualiza constantemente en la medida que sigue presente en la memoria colectiva. Es decir, se le otorga valor, el patrimonio no existe en sí mismo, en tanto es una construcción de significados. No puede conservarse como objeto, sino en la identidad asociada. El territorio carbonífero convive con la ruina, es decir, con un objeto que no ha sido conservado y donde se observa paulatinamente su desaparición, diluyéndose en el tiempo y el espacio; aun así, es posible encontrar en algunos miembros de la comunidad una identidad que subsiste, que se retroalimenta de lo material y reactualiza la memoria social y el espacio vivido, reactualizando cotidianamente su sentido patrimonial. Así, como en Puerto Cristal se reactualiza en la visita anual de los excristalinos a su poblado a visitar a sus muertos (Fig. 5), a dar vida a las casas, a los casinos y a la fiesta colectiva. Hasta que la visita termina y cada uno vuelve a su lugar, cuando el objeto vuelve a ser monumento, que puede ser visitado por otros (turistas) que le otorgan otros significados. Bajo esta perspectiva es posible intervenir y darle nuevos usos al objeto monumento, pero si la identidad y los significados atribuidos se mantienen, el patrimonio subsiste.

La asignación de valor patrimonial que se le otorga a un territorio, siguiendo a Barreiro (2012), es un proceso de producción en el que interactúan diferentes agentes (expertos, institucionales y sociales). Los sujetos patrimoniales, según Carrión (2010), son los que reconocen, protegen y se apropian del patrimonio, lo que implica que debe haber una relación simétrica entre todas las entidades involucradas, que actúan en conjunto para dar curso a un proceso de patrimonialización o de puesta en valor, en relación 
constante con el objeto, cuyo contenido son las significaciones entendidas procesualmente y, por lo tanto, reconociendo su dinamismo. Una cuestión clave es preguntarse si al desaparecer el objeto, es decir lo material, el patrimonio desaparece. La respuesta emerge de la experiencia de los sujetos que se reactualizan, al transformar su experiencia en un patrimonio inmaterial y por lo tanto un patrimonio vivo. Eso es lo que sucede con estas comunidades estudiadas, su carácter patrimonial excede la materialidad. A pesar de que lo estén viendo paulatinamente desaparecer (en Schwager el Economato, el pique Arenas y su fallido museo, ver Fig. 6), parte de esta comunidad porfía y pone su experiencia por delante, se organizan, se juntan a recordar su experiencia vivida y van dando valor a los espacios (hoy transformados) en cuyo subsuelo todavía pueden sentir el sonido de la sirena que llamaba a los turnos, o ver la imagen del minero con su cuerpo impregnado de hollín, o las risas en el gimnasio en la celebración de una fiesta, etc. O como sucede en Puerto Cristal, el monumento existe, está protegido por la ley, tiene un dueño que lo rentabiliza a través del turismo industrial y sus exhabitantes pueden visitarlo en el mejor de los casos una vez al año. Sin embargo, como plantea Olivera (2011), han llevado "su patrimonio inmaterial a donde quiera que emigren, en un rincón del alma en donde guardan celosamente sus costumbres y expresiones intangibles” (p. 673), dándole vida en el lugar de origen y en el lugar de destino.

A modo de síntesis, nos preguntamos ¿cómo pueden proyectarse estos territorios desde la memoria, incluyendo las definiciones culturales del patrimonio? ¿cómo incorporar en el debate el problema de la turistificación? Como plantean Criado-Boado y Barreiro (2013), el patrimonio debe ser comprendido como una huella entre la memoria y el olvido, incorporando los entes materiales y las ideas que se valoran socialmente y que constituyen bienes patrimoniales y aquellos que pueden alcanzar dicho estatus, eso es lo que le da sentido a la pregunta por la turistificación del sitio. Es decir, cómo convivirá la experiencia pasada de quienes habitaron y/o habitan el lugar y que han construido su identidad en el pasado minero (que conoce de tragedias, explotación laboral, organización y resistencias, que ha seleccionado la memoria para poner en valor su apego al territorio, el pasado más luminoso asociado a las prácticas paternalistas $y$ el fortalecimiento de una comunidad), con los turistas que recorren el territorio sin memoria, que le otorgan un sentido al monumento o a la tradición, transformada en fiesta o celebración, que valoran el paisaje natural, como sucede en la Patagonia chilena y se maravillan al reconocer en ese territorio casi prístino un enclave minero. Observamos en el territorio la difusa experiencia del esfuerzo de trabajadores/as chilenos/as por aportar al progreso económico del país y de cómo era posible pensar el desarrollo de la mano del bienestar de los/as trabajadores/as y sus familias, y por otro lado observamos los esfuerzos por transformar esas experiencias en una mercancía o en un bien patrimonial que pueda ser rentable turísticamente. Ahí está el desafío y tensión que viven actualmente las comunidades. 


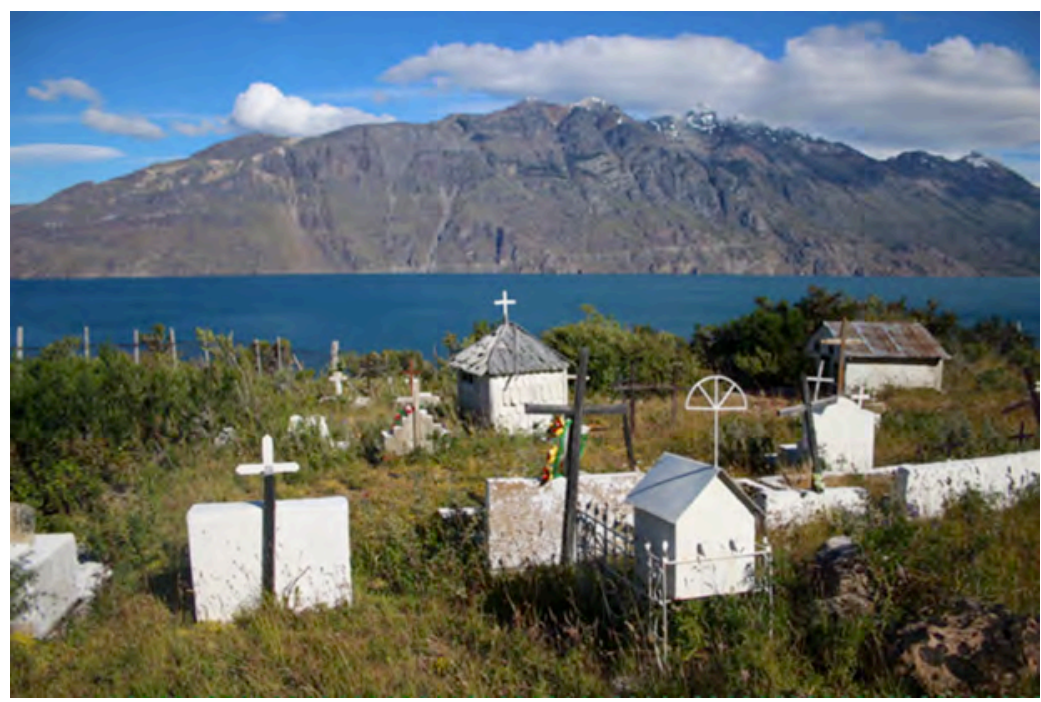

Fig. 5. Cementerio en Puerto Cristal.

Fuente: Proyecto CONICYT-PIA Soc 1403. Trabajo de terreno, enero 2018.

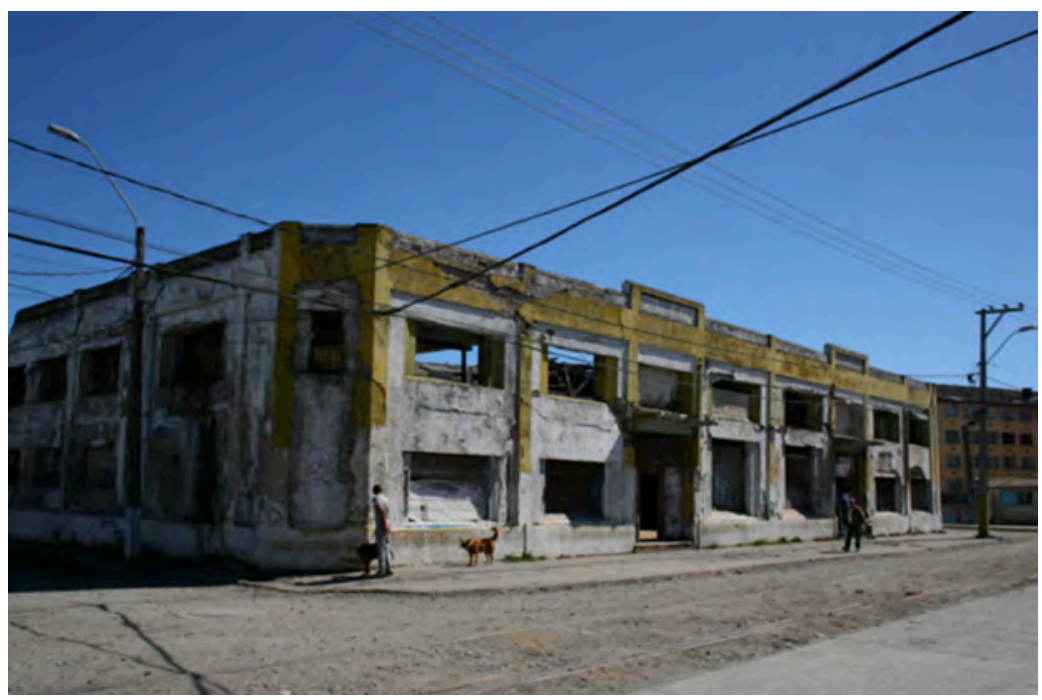

Fig. 6. Ruinas del Economato en Schwager.

Fuente: Archivo de Arquitectura, Universidad del Bío-Bío.

\section{Fuentes}

La Información, periódico de la Compañía Carbonífera y Fundición Schwager, 1937-1945. Talleres de memoria colectiva con extrabajadores y esposas de extrabajadores de Schwager en el marco del Proyecto Fondecyt 1140461.

Entrevistas a extrabajadores de Schwager, en el marco del Proyecto Fondecyt 1140461.

Taller de memoria colectiva con Agrupación de Social y Cultural Los Cristalino, en el marco del Proyecto Anillos CONICYT-PIA Soc 1403. 


\section{REFERENCIAS}

Alarcón, R. (1996). La refundación de las ciudades mineras. Seminario de Título, Carrera de Arquitectura, Universidad del Bio-Bío, Concepción, Chile.

Alvarado, G. (2016). Industrias paternalistas y sociabilidad obrera. Relación alcohol y trabajo en Tomé, Coronel y Talcahuano (1939-1973). Seminario de Habilitación para optar al grado de Licenciatura en Historia, Universidad de Concepción.

Baros, M. (1996). El Teniente. Los hombres del mineral. 1905-1945. Santiago: CODELCO.

Baros, M. (2006). Una historia de pioneros: Potrerillos y El Salvador. Santiago, Chile: CODELCO. Barreiro, D. (2012). Arqueología aplicada y patrimonio: memoria y utopía. Complutum, 23(2), 33-50. http://dx.doi.org/10.5209/rev_CMPL.2012.v23.n2.40874

Benedetti, L. (2019). La cuestión social en Concepción y los centros mineros de Coronel y Lota (1885-1910). Concepción: Ediciones Archivo Histórico de Concepción.

Brieva, K. (2002). Asentamiento carbonífero Barrio Maule. Seminario de Título Carrera de Arquitectura, Universidad del Bio-Bío, Concepción, Chile.

Brito, A. (2018). Memoria colectiva y construcción de territorio: auge y despojo de una cultura industrial. Los casos de la fábrica textil Bellavista-Tomé y la carbonífera Schwager en Coronel (1970-2007). Izquierdas, 42, 1-29. http://dx.doi.org/10.4067/S071850492018000500001.

Brito, A., \& Ganter, R. (2015). Cuerpos habitados, espacios modelados: el caso de la Siderúrgica Huachipato, 1940-1970. Historia 396, 5(1), 11-36.

Brito, A., \& Contreras, T. (2018). El "obrero soñado": masculinidades mineras en la industria del carbón en Puchoco-Schwager, 1929-1994. En N. Fuller (Ed.), Difícil ser hombre. Nuevas masculinidades latinoamericanas (pp. 108-139). Lima: Fondo Editorial de la Pontificia Universidad Católica del Perú.

Carrasco, C. (2009). Mujeres, sostenibilidad y deuda social. Revista de Educación, número extraordinario, 169-191.

Carrasco, C., Borderías, C., \& Torns, T. (Eds.) (2011). El trabajo de cuidados. Historia, teoría y política. Madrid, España: Catarata.

Carrión, F. (2010). El laberinto de las centralidades históricas en América Latina. El centro histórico como objeto de deseo. Quito: Ministerio de Cultura del Ecuador.

Criado-Boado, F., \& Barreiro, D. (2013). El patrimonio era otra cosa. Estudios Atacameños Arqueología y Antropología Surandinas, 45, 5-18. http://dx.doi.org/10.4067/S071810432013000100002.

Delgado, M. (2007). Lo común y lo colectivo. Barcelona: Universitat de Barcelona.

Díaz, M. (1962). Labor del Servicio Social en las Compañías Carboníferas de Lota y Schwager en el año 1961. Memoria de Prueba para optar al título de Asistente Social, Universidad de Concepción, Chile.

Dormaels, M. (2011). Patrimonio, patrimonialización e identidad. Hacia una hermeneútica del 
patrimonio. Revista Herencia, 24(1 y 2), 7-14.

Dos Santos, J. (2014). Le Familistêre de Guise: ¿un paternalisme de gauche? Revue internacionale de l'économie sociale, 332, 62-72. https://doi.org/10.7202/1024823ar

Ffrench-Davis, R., Muñoz, O., Benavente, J. M., \& Crespi, G. (2000). The Industrialization of Chile during Protectionism, 1940-82. In E. Cárdenas, J. A. Ocampo \& R. Thorp (Eds.), An Economic History of Twentieth-Century Latin America: Volume 3: Industrialization and the State in Latin America: The Postwar Years (pp. 114-153). Londres: Palgrave Macmillan. https://doi.org/10.1057/9780230595682_5

Fuentes, P. (2015). Del familisterio al condensador social. El colectivo Chollín como arquetipo moderno. Revista AUS, 17. http://doi.org/10.4206/aus.2015.n17-09.

Fuentes, P., \& Mayorga, E. (2012). El edificio Chollín: Arquetipo de la promenade arquitectural en Chile. Arquitecturas del Sur, 40, 6-15.

Ganter, R., \& Brito, A. (2017). Cartografías de lo cotidiano: usos, relatos y disposiciones del espacio en el contexto de la industria minera y textil del Gran Concepción (1940-1973). Revista Austral de Ciencias Sociales, 33, 37-57. https://doi.org/10.4206/rev.austral. cienc.soc.2017.n33-03.

Ganter, R., Sandoval, D., García, D., \& De la Fuente, H. (2015). Topofilia y Cartografías Participativas en el sur de Chile. La experiencia comparada en las ciudades de TemucoPadre las Casas, Valdivia y el Gran Concepción. Prisma Social, 15, 440-491.

Garrido, S. (2014). Evolución de la huelga en la Gran Minería del Cobre 1911-1991. Perfiles Económicos, 2 (Diciembre 2016), 131-162.

Garrigós, J. (2006). Presentación Frédéric Le Play en el origen de la preocupación por la cuestión social. Reis, 115, 321-333.

Godoy, M. (2015). Las casas de la empresa: Paternalismo industrial y construcción de espacio urbano en Chile. Lota, 1900-1950. Universum, 30(1), pp. 115-136. http://dx.doi. org/10.4067/S0718-23762015000100008.

González, S. (2002). Hombres y mujeres de la Pampa. Tarapacá en el ciclo de expansión del salitre. Santiago de Chile: LOM Ediciones.

González, S. (2013). Del descampado de Atacama a la sociedad del salitre. Balance y perspectivas en el estudio del ciclo de expansión del nitrato. En S. González (Ed.), La sociedad del salitre: Protagonistas, migraciones, cultura urbana y espacios públicos (pp. 23-38). Santiago: RIL Editores.

González, S. (2014). Las inflexiones del inicio y término del ciclo de expansión del salitre (1872-1919). Una crítica al nacionalismo metodológico. Diálogo Andino, 45, 39-49. http://dx.doi.org/10.4067/S0719-26812014000300005.

González, J. A. (2017). La épica del salitre en el desierto de Atacama: 1880-1967: Trabajo, tecnologías, vida cotidiana, conflicto y cultura. Antogasta: Ediciones Universitarias.

Grez, S. (1995). La “Cuestión Social” en Chile: Ideas y Debates Precursores, 1804-1902. Santiago: Dirección de Bibliotecas, Archivo y Museos, Centro de Investigaciones Diego 
Barros Arana.

Ibáñez, A. (1994). El liderazgo en los gremios empresariales y su contribución al desarrollo del Estado Moderno durante la década del treinta: El fomento a la producción y los antecedentes de CORFO. Historia, 28, 183-216.

Illanes, M. A. (2003). Chile Des-centrado. Formación socio-cultural republicana y transición capitalista (1810-1910). Santiago de Chile: LOM Ediciones.

Lavoz, M., \& Shejade, S. (2010). La experiencia de un proceso. Percepciones de los hombres y mujeres de Coronel acerca de la reconversión laboral y productiva. Seminario de Título para optar al grado académico de Licenciado en Educación, Título de Profesor de Historia y Geografía, Universidad de Concepción, Chile.

Leidenberger, G. (2004). Proximidad y diferenciación: el manejo del concepto de espacio en la historiografía urbana. Historia y Grafía, 22, 51-77.

Lefebvre, H. (2013). La producción del espacio. España: Capitán Swing.

Lemiez, G. (2013). Relaciones laborales paternalistas en la industria del cemento. El caso de Avellaneda, Olavarría 1935-1973.

Lindón, A. (2002). La construcción social del territorio y los modos de vida en la periferia metropolitana. Territorios 7, 27-41.

López, M., \& Becerra, M. (2018). Minería. En Brito et al. Industria y habitar colectivo. Conjuntos habitacionales en el sur de Chile. Concepción: Chile.

Martinic, M. (2014). De la Trapananda al Aysén. Una mirada reflexiva sobre el acontecer de la Región de Aysén desde la Prehistoria hasta nuestros días. Santiago de Chile: Ediciones Fundación Río Baker.

Matus, M. (2013). Fulgor y muerte del jornal salitrero en Chile, 1899-1930. En S. González (Ed.), La sociedad del salitre: Protagonistas, migraciones, cultura urbana y espacios públicos (pp. 503-534). Santiago: RIL Editores.

Mazzei, L. (1997). Los británicos y el carbón en Chile. Atenea, Revista de Ciencia, Arte y Literatura, 475, 137-167.

Mazzei, L. (2001). Expansión de gestiones empresariales desde la minería del norte a la del carbón, (Chile, S. XIX). En J. Pérez Cebada (Coord.). Minería y medio ambiente en perspectiva histórica. Collectánea, 50 (pp. 105-128). Huelva: Universidad de Huelva.

Meller, P. (1998). Un siglo de economía política chilena (1890-1990). Santiago: Editorial Andrés Bello.

Muñiz, J. (2007). La construcción social del espacio en el poblado minero metalúrgico de Arnao (Asturias), 1855-1937. Scripta Nova. Revista Electrónica de Geografía y Ciencias Sociales, XI, 249.

Muñiz, J. (2011). Huertos Obreros y paternalismo industrial en la Société des Mines de Lens (Francia) a principios del siglo XX. Historia Contemporánea, 43, 721-747.

Muñoz, O., \& Arriagada, A. M. (1977). Orígenes políticos y económicos del estado empresarial en Chile. CIEPLAN -Corporación de Investigaciones Económicas para Latinoamérica, 


\section{A. BRITO}

Santiago de Chile.

Olivera, A. (2011). Patrimonio inmaterial, recurso turístico y espíritu de los territorios. Cuadernos de Turismo, 27, 663-677.

Ortega, L. (2008). Las transformaciones en el mercado internacional del cobre y la decadencia de la región minera tradicional de Chile, 1875-1920. Tiempo y Espacio, 20, 6-26.

Ortega, L. (2018). La economía política de la industrialización a través de un siglo. En I. Jaksic, C. Robles \& A. Estefane (Eds.), Historia política de Chile, 1810-2010. Tomo III. Problemas económicos (pp. 141-170). Santiago: Fondo de Cultura Económica.

Ortega, L., \& Pinto, J. (1990). Expansión minera y desarrollo industrial: Un caso de desarrollo asociado (Chile, 1850-1914). Santiago: Universidad de Santiago de Chile.

Oslender, U. (2002). Espacio, Lugar y Movimientos Sociales: "hacia una espacialidad de resistencia”. Scripta Nova Revista Electrónica de Geografía y Ciencias Sociales, VI, 115.

Pérez, L. (2008). El barrio Puchoco en Schwager. Cuando la industria construye el paisaje cultural. Urbano, 11(18), 47-58.

Pinto, J. (2003). La formación del estado y la nación, y el pueblo mapuche: De la inclusión a la exclusión. Santiago: Dirección de Bibliotecas y Museos.

Pinto, J. (2007). Desgarros y utopías en la pampa salitrera. La consolidación de la identidad obrera en tiempos de la cuestión social (1890-1923). Santiago: LOM Ediciones,.

Prats, Ll. (2000). El concepto de patrimonio cultural. Cuadernos de Antropología social, 11. Universidad de Buenos Aires. https://doi.org/10.34096/cas.i11.4709

Robles, C. (2009). La producción agropecuaria chilena en la "Era del Salitre" (1880-1930). América Latina en la Historia Económica, 32, 113-137.

Salazar, G. (1985). Labradores, peones y proletarios. Formación y crisis de la sociedad popular chilena del siglo XIX. Santiago de Chile: Ediciones SUR.

San Francisco, A., Bellester, B., Sepúlveda, J., Lasnibat, M., \& Sepúlveda, A. (2009). Flor de Chile. Vida y Salitre en el Cantón de Taltal. Cuadernos de Historia Marxista, I(3), 1-118.

Sierra, J. (1990). El obrero soñado. Ensayo sobre el paternalismo industrial. Asturias 18601918. Madrid: Siglo XXI.

Soja, E. (1997). El tercer espacio. Ampliando el horizonte de la imaginación geográfica. Geográfikos, 8, 71-76.

Sznol, F. (2007). Geografía de la Resistencia. Protesta social, formas de apropiación y transformación del espacio urbano en la Argentina (1996-2006). Revista THEOMAI. Estudios sobre Sociedad y Desarrollo, $15\left(1^{\circ}\right.$ semestre).

Terradas i Saborit, I. (1994). La qüestió de les colònies industrials. L'exemple de l'Ametlla de Merola. Cataluña: Imprenta Orriols.

Tilly, Ch. (1984). Grandes estructuras, procesos amplios, comparaciones enormes. México, Alianza Editorial.

Valenzuela, M. (2013). La huelga “Grande” del carbón en Lota, Voronel y Curanilahue de 1920. Historia Actual Online, 32(otoño, 2013), 73-89. 
Van der Linden, M. (1999). Hacer historia comparativa del trabajo: algunos preliminares esenciales. Historia Social, 33, 111-131.

Venegas, H. (2015). Políticas de bienestar y control social en la minería del carbón. Las experiencias de Lota y Coronel en el siglo XX. Atenea, 511(1º sem), 221-245.

Venegas, H., \& Morales, D. (2015). El despliegue del paternalismo industrial en la Compañía Minera e Industrial de Chile (1920-1940). Historia Crítica, 58, 117-136.

Venegas, H., \& Morales, D. (2017). Un caso de paternalismo industrial en Tomé: Familia, espacio urbano y sociabilidad de los obreros textiles (1920-1940). Historia, 50(1), 273302.

Vergara, Á. (2004). Conflicto y Modernización en la Gran Minería del Cobre (1950-1970). Historia, 37(2), 419-436. https://doi.org/10.4067/S0717-71942004000200006

Vergara, Á. (2012). Precios fijos y raciones: la Anaconda Company en Chile entre 1932 y 1958. Investigaciones de Historia Económica, 8(3), 135-143. https://doi.org/10.1016/j. ihe.2012.04.002

Vergara, Á. (2013). Paternalismo industrial, empresa extranjera y campamentos mineros en América Latina: un esfuerzo de historia laboral y transnacional. Avances del Cesor, 10, 113-128. 